\title{
Paradigma Metode Pemahaman Hadis Klasik dan Modern: Perspektif Analisis Wacana
}

\author{
M. Khoirul Huda \\ chairool_hoeda@yahoo.co.id
}

\begin{abstract}
Abstrak: Tulisan ini mendiskusikan paradigma yang berada di balik metode pemahaman hadis klasik dan modern. Kesimpulan sementara, metode pemahaman hadis klasik -yang diwakili ilmu matan hadis, dibangun di atas dasar paradigma positivis, dan metode modern dibangun di atas paradigma konstruktivis. Penelitian juga mengarah kepada kesimpulan belum berkembangnya metode pemahaman hadis berdasar paradigma kritis. Dalam penelitian ini, dua variabel yang diteliti adalah ilmu matan hadis sebagai instrumen pemahaman yang populer dan pemahaman pemilahan peran Nabi berdasar maqüsid al-sharīah yang dikembangkan Ibn 'Āshür (1973 M.). Kedua variabel tersebut dipotret dalam kerangka pergeseran paradigma analisis wacana.
\end{abstract}

\section{Kata Kunci: paradigma, metode, pemahaman, hadis, wacana}

\section{Pendahuluan}

Hadis Nabi saw. sejak pertama kali diungkapkan kemudian dikutip, disampaikan kepada orang lain, membentuk tradisi periwayatan, lalu dikodifikasikan dalam kitab-kitab hadis dan kemudian kitab-kitab syarah hadis, merupakan rangkaian teks. Ia bahkan menjadi teks primer yang mendorong produksi teks-teks sekunder dalam peradaban Islam. Jika Nasr Hamid Abu Zayd menempatkan Alquran sebagai teks yang menjadi poros peradaban Islam (nașsan mihwariyyan), ${ }^{1}$ maka berbeda dengan George Tharabisi yang melihat hadis sebagai poros "pandangan dunia" dalam Islam. ${ }^{2}$ Sebagai sebuah teks, dan inilah bentuk tekstualitas hadis Nabi, hadis terbentuk dari susunan kata, kalimat, dan kemudian wacana yang terdiri dari bagian-bagian sub-wacana yang memiliki pengertian dan fungsinya sendiri.

Formasi diskursif hadis tidak hanya melibatkan hadis an sich. Namun juga melibatkan aspek lain di luar narasi hadis seperti penerima narasi hadis, penafsiran-penafsiran terhadapnya, konteks sosial-politik yang melingkupinya. Dengan demikian, hadis sejatinya tidak berdiri sendiri melainkan didukung oleh penafsir, penafsiran dan konteks sosial yang meliputi keduanya. Di sinilah bisa dilihat hubungan teks hadis dengan dunia sosial umat Islam yang faktanya 
dihubungkan dengan penafsiran atau pemahaman terhadapnya. Penafsiran atau pemahaman terhadap teks hadis kemudian menjadi lebih penting karena ia menentukan sikap-sikap Muslim terhadap dunia yang dihadapinya. Pemahaman hadis mengarah pada proses, cara serta perbuatan memahami atau memahamkan hadis Nabi saw. Bila dirunut akar sejarahnya, praktik memahami hadis sudah muncul sejak beliau menyampaikan sabdanya kepada orang lain (baca: sahabat). Sahabat yang mendengar sabda-sabda Rasulullah saw. kemudian memahaminya dengan kadar yang dapat mereka tangkap. Menurut Ibn Qayyim al-Jauziyyah, pada masa ini, sudah terdapat polarisasi pemahaman ke dalam model pemahaman literalis (asḥāb al-zähir) dan esensialis (aṣhāb al$\left.m a^{\prime} \bar{a} n \bar{\imath}\right)$. Kondisi ini terus berkembang dan mengerucut pada lahirnya dua model pemahaman teks yang sangat berpengaruh dalam tradisi Islam, yaitu kelompok ahl al-hadìth dan ahl al-ra' . $^{3}$

Pada abad kedua hijriah, karena kondisi sosial yang berubah, masyarakat Muslim mengembangkan cara-cara memahami hadis yang beragam. Misalnya, karena terjadi perubahan komposisi masyarakat Muslim dari mayoritas Arab menjadi dominasi non-Arab, dimana mereka memiliki keterbatasan dalam mengakses serta menggunakan bahasa Arab, muncul fenomena laḥn atau kesalahan berbahasa. Lạ̣n secara umum berhubungan dengan ketidakmampuan berbahasa dengan baik. Hal ini juga berpengaruh pada semakin banyaknya kosa-kata yang tidak dikenal dalam hadis-hadis Nabi saw. Menurut Ibn al-Jawzī, inilah yang melahirkan disiplin gharīb al-hadìth. ${ }^{4}$ Bersamaan dengan itu, pertemuan kebudayaan Arab yang sederhana dan Non-Arab yang komplek, menimbulkan banyak pertanyaan mengenai ajaran-ajaran dasar yang termuat dalam hadis-hadis Nabi saw. Masuknya tradisi berfikir rasional misalnya, yang digunakan untuk menjelaskan peristiwa-peristiwa sosial dalam sejarah awal Muslim, telah melahirkan polarisasi sektarian di tubuh umat Islam. Hasilnya, lahir sejumlah sekte keagamaan yang sebagian di antaranya menolak penggunaan hadis (ahad) dalam rujukan keagamaan. Penolakan ini didasarkan kepada fakta bahwa beberapa hadis hadis disinyalir bertentangan satu dengan lainnya. Hal ini membuat sebagian Muslim saat itu berfikir bahwa hadis ahad menyimpan sejumlah keraguan yang tidak bisa diterima. Pertentangan ini kemudian melahirkan problem kontradiksi dalam proses pemahaman hadishadis Nabi saw. Sejumlah sarjana bangkit menjawab problem ini dan melahirkan diskursus keilmuan mukhtalif al-hadith. ${ }^{5}$

Di sini, perubahan sosial yang berdampak pada perubahan cara berfikir masyarakat, berakibat pada lahirnya cara-cara memahami hadis yang dinamis. Pada era modern, peruabahan sosial juga berpengaruh pada perubahan cara 
berfikir dan bersikap umat Islam terhadap hadis Nabi saw. Tulisan ini akan mengeksplorasi salah satu simpul perubahan tersebut melalui kajian terhadap tokoh modern yang dinilai memiliki peran signifikan dalam merumuskan metode pemahaman hadis. Penulis mendiskusikan pemikiran hadis Muhammad al-Ṭāhir Ibn 'Āshūr. Sumber utama tulisan ini adalah karya Ibn 'Āshūr berjudul Maqāsid al-Sharīah al-Islamiyyah. Dalam menganalisis sumbangan Ibn 'Āshūr, penulis menggunakan teori analisis wacana terutama yang menjelaskan pergeseran paradigma dalam studi analisis wacana. Untuk menemukan perbandingannya, penulis menggunakan ilmu matan hadis sebagai representasi metode pemahaman hadis klasik yang dinilai memiliki paradigma berbeda dengan paradigma yang mendasari metode pemahaman Ibn 'Āshūr. Ilmu matan hadis dipilih sebagai 'pembanding' dengan metode yang dikembangkan Ibn 'Āshūr berdasarkan dua asumsi. Pertama, ilmu matan hadis merupakan instrumen pemahaman yang telah berkembang sebelum Ibn 'Āshūr dan menjadi metode dominan yang digunakan dalam dunia Muslim. Kedua, ilmu matan hadis merupakan disiplin penafsiran hadis yang dibentuk oleh situasi tertentu sesuai perkembangan sosial dan ilmu pengetahuan.

Penggunaan teori pergeseran paradigma analisis wacana dalam penelitian ini didasarkan kepada asumsi bahwa hadis merupakan ujaran yang terstruktur dan membentuk kesatuan wacana. Karenanya, dipandang cukup relevan penggunaan teori ini dalam menganalisis model pembacaan wacana melalui teori-teori pergeseran paradigma dalam analisis wacana.

Analisis wacana merupakan salah satu disiplin yang dikembangkan dalam studi bahasa/pemakaian bahasa. Terdapat tiga paradigma utama yang berkembang dalam studi ini. Pertama, dan ini yang paling awal berkembang, paradigma positivisme-empiris yang menekankan pentingnya struktur internal bahasa. Bahasa diyakini dapat merepresentasikan pikiran manusia secara valid. Karenanya, analisis ditenkankan pada analisis bahasa; kosa kata, sintaksis dan ketepatan diksi. Di sini, bahasa mengalami objektifikasi dan positivisasi. Bahasa dipisahkan dari manusianya. Kaitannya dengan analisis wacana, konsekuensi logis pemahaman ini adalah orang tidak perlu mengetahui makna-makna subjektif atau nilai yang mendasari pernyataan, sebab yang penting adalah apakah pernyataan itu dilontarkan secara benar menurut kaidah sintaksis dan semantis atau tidak. Oleh sebab itu, paradigma ini mempunyai ciri khas memisahkan antara pemikiran dan realitas. Objek analisisnya adalah tata aturan kalimat, bahasa dan pengertian bersama yang terkandung dalam sebuah teks. Wacana kemudian diukur melalui pertimbangan kebenaran/ketidakbenaran sintaksis dan semantis. Kedua, paradigma konstruktivisme yang dipengaruhi 
fenomenologi. Aliran ini menolak aliran positivisme bahasa yang memisahkan subjek dan objek bahasa. Konstruktivisme memandang subjek bahasa memiliki kemampuan kontrol terhadap bahasa yang digunakan ketika berwacana. Bahasa merupakan suatu pola yang memiliki tujuan-tujuan dari subjek bahasa. Pernyataan atau pewacanaan merupakan upaya penciptaan makna-makna oleh pengarangnya, tindakan pembentukan diri serta pengungkapan jati dirinya. Oleh karena itu, analisis wacana dimaksudkan sebagai suatu analisis yang "membongkar" makna-makna dan tujuan-tujuan tertentu. Pelacakan kembali makna atau tujuan subjek bahasa bisa dilakukan dengan menempatkan diri pada posisi pembicara dengan penafsiran mengikuti struktur makna dari pembicara. Ketiga, paradigma kritis. Pandangan ini ingin mengoreksi pandangan konstruktivisme yang kurang sensitif pada proses produksi dan reproduksi makna yang terjadi secara historis maupun institusional. Dalam arti yang lebih luas, paradigma konstruktivisme mengabaikan peran kekuatan dan kekuasaan yang membentuk subjek bahasa. Subjek bahasa dalam paradigma kritis dinilai tidak dapat melepaskan diri dari kekuatan sosial dan keberpihakan yang ada di masyarakatnya. Dengan demikian pada dasarnya bahasa yang digunakan subjek tidak netral, tapi selalu berpihak. Paradigma kritis ingin membongkar jaringan kuasa yang meliputi sebuah wacana. Bahasa selalu terlibat dalam hubungan kekuasaan, terutama dalam pembentukan subjek dan berbagai tindakanan representasi yang terdapat dalam masyarakat. Analisis wacana yang didasari paradigma kritis ini sering disebut analisis wacana kritis (Critical Discourse Analysis/CDA). ${ }^{6}$ Dalam ketiga paradigma inilah ilmu matan hadis akan diteropong.

Tulisan ini dibagi ke dalam beberapa bagian. Bagian pertama merupakan pendahuluan. Bagian kedua akan membahas ilmu matan hadis sebagai metode pemahaman teks hadis. Tiga ilmu matan hadis yang akan dianalisis adalah mukhtalif al-ḩadìth, gharīb al-hadìth, dan asbäb al-wurüd. Bagian ketia akan membahas metode pemahaman hadis Ibn 'Āshūr melalui kajian terhadap kitab Maqāsid al-Sharīah al-Islamiyyah. Bagian kelima adalah simpulan dari dua pembahasan pokok sebelumnya. Simpulan ini berisi jawaban untuk pertanyaan apa jenis kategori paradigma metode-metode pemahaman hadis klasik dan modern?

\section{Ilmu Matan Hadis: Sebuah Pembacaan Positivistik}

Ilmu matan hadis merupakan salah satu sub disiplin keilmuan hadis ('ulūm al-hadìth). Terdiri dari empat cabang ilmu; mukhtalif al-hadìth (studi aspek kontradiksi hadis-hadis nabi), gharīb al-hadìth (kajian redaksi asing), asbāb 
wurūd al-hadīth (studi konteks sabda nabi) dan nāsikh wa mansükh al-ahādìth (studi abrogasi dalam hadis). Objek kajian keempat ilmu tersebut ialah teks (hadis). Disiplin-disiplin itu dapat disebut studi teks Islam. Pada umumnya, disiplin-disiplin tersebut digunakan dalam kerangka inferensi hukum (istinbāt al-ậkām) dengan fokus garapan yang berbeda dari anatomi wacana teks yang menjadi objek kajiannya.

Sebagai model berinteraksi dengan teks, dalam lingkup yang lebih luas "wacana", ilmu matan dibangun di atas sebuah paradigma tertentu. Menjadi pertanyaan penting paradigma apakah yang mendasari model pembacaan wacana ala ilmu matan hadis? Dalam konteks ini, penulis melihat bahwa ilmu matan hadis masuk dalam model pembacaan wacana dengan paradigma positivis. Hal ini didasarkan kepada argumen bahwa tiga sub disiplin ilmu matan hadis lebih fokus kepada teks hadis, dan mengabaikan intensi/niat/maksud Nabi saw. Di bawah penulis coba paparkan mengenai model pembacaan teks hadis melalui tiga sub disiplin ilmu matan hadis.

\section{Ilm Mukhtalif al-Hadith: Pembacaan Berbasis Kontradiksi Teks}

Mukhtalif al-Hadith bergerak dalam wacana kontradiksi yang menghampiri hadis-hadis Nabi saw. Terlepas dari apakah kontradiksi itu bersifat inheren alias menjadi unsur laten dalam hadis ataukah sekadar kontradiksi persepsional seorang pembaca hadis. Penulis melihat bahwa kontradiksi hanya sebatas gejala mental yang mengkonstruksi satuan informasi yang berbeda-beda di atas asumsi-asumsi yang lemah. ${ }^{7}$ Kontradiksi yang lahir akibat pembandingan satu teks dengan teks lainnya, diselesaikan dengan menggunakan sejumlah teori. AlShāfi' ${ }^{`}$ misalnya menawarkan paling tidak enam (6) metode operasional yang meliputi: (1) al-jam; (2) nasakh, (3) ikhtiläf min jihat ibāhah, (4) mujmalmufassar, (5) tarjih bi al-munasabah dan (6) tarjih al-riwayah. ${ }^{8}$ Keenam metode tersebut dapat disederhanakan ke dalam tiga prinsip: jam ' (kompromi), tarjīh (preferensi) dan nasakh (abrogasi).

Mekanisme jam' dilakukan dengan cara menganggap semua teks hadis dapat dipakai dalam kondisi yang berbeda. Sebagai contoh hadis berikut.

$$
\text { عن ابن عباس أن رسول الله وضأ وجهاه ويدياه ومسح برأسه مرة مرة }
$$

Dari Ibn 'Abbās bahwa Rasulullah saw. mewudukan wajahnya, kedua tangan dan mengusap (rambut) kepalanya masing-masing satu kali. ${ }^{9}$ 
Dari Humran Mawla 'Uthmān bin 'Affān bahwa Nabi saw. berwudu masingmasing tiga kali. ${ }^{10}$

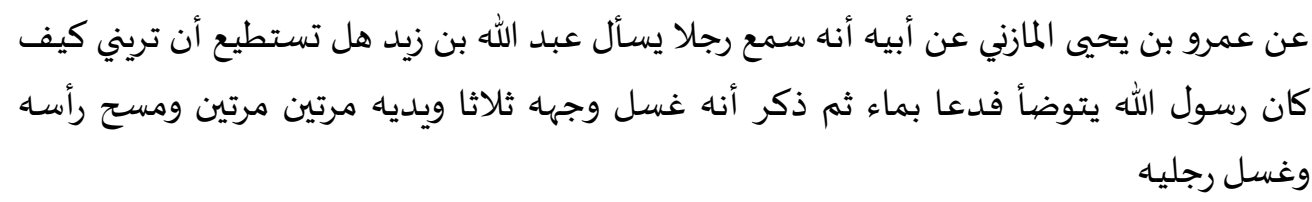

Dari 'Amr bin Yahya al-Māzini dari ayahnya bahwa dia mendengar seorang laki-laki bertanya kepada 'Abdullah bin Zayd apakah Anda bisa memperlihatkan kepadaku cara Rasulullah saw. berwudu? Kemudian 'Abdullah minta dibawakan air wudu, lalu dia menyebutkan bahwa Nabi saw. membasuh wajahnya tiga kali, kedua tangannya masing-masing dua kali dan mengusap kepala dan membasuh kedua kakinya (masing-masing satu kali). ${ }^{11}$

Ketiga hadis di atas menunjukkan bilangan yang berbeda-beda dalam ritual berwudu. Menurut al-Shāfí'ī, ketiga hadis itu harus dipahami dalam konteks kebolehan. Seseorang boleh membasuh sekali, dua kali atau tiga kali. Sekali basuh merupakan bilangan minimal dan tiga kali merupakan bilangan maksimal (paling sempurna). Ketiga hadis di atas bukan dalam konteks halalharam atau perintah-larangan. Tapi keutamaan. Dari sini orang diberi kesempatan memilih bilangan yang sesuai dengan kondisi yang dihadapinya. ${ }^{12}$ Di sini, ketiga teks tersebut dapat dipakai sesuai kondisi yang ada. Teks tidak diabaikan, atau didiskualifikasi otoritasnya sebagai dasar praktik ibadah. Ia hanya ditempatkan dalam konteks yang berbeda-beda. Dalam praktik pemahaman melalui mukhtalif al-hadīth ini (baca: jam'), pembaca hadis diarahkan memperhatikan kontradiksi yang ada dalam beberapa teks. lalu menempatkan masing-masing teks dalam ruang yang berbeda ketika dipraktikkan. Hal-hal di luar teks diabaikan begitu saja, tanpa melihat kondisi kemunculan teks tersebut misalnya.

Contoh penggunaan preferensi (tarjīh) dapat dilihat pada hadis tentang mengangnkat tangan saat salat berikut,

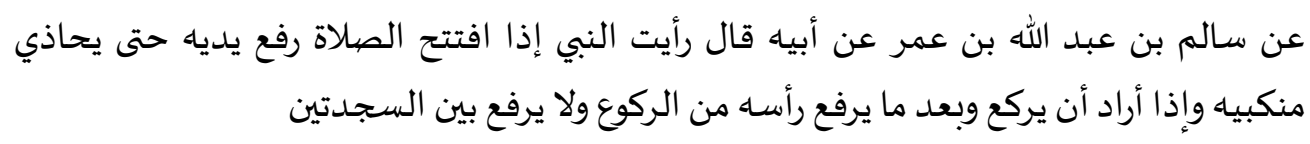

Dari Sālim bin 'Abdillah bin 'Umar dari ayahnya yang berkata, "Aku melihat Nabi saw. mengawali salatnya dengan mengangkat kedua tangannya sampai berhadapan dengan kedua pundaknya, dan ketika beliau hendak ruku' dan 
setelah mengangkat kepala dari ruku', dan beliau tidak mengangkat tangan di antara dua sujud. ${ }^{13}$

الصناة عبد الرحمن بن أبي ليلى عن البراء بن عازب قال : رأيت النبي صلى الله عليه و سلم إذا افتتح يعود.

Dari 'Abd al-Rahman bin Abī Layla dari al-Bara' bin 'Āzib yang berkata, "Aku melihat Nabi saw. ketika mengawali salat beliau mengangkat kedua tangannya." Sufyān berkata, "Kemudian aku datang ke kota Kufah, lalu bertemu Yazīd di sana. Aku mendengarnya meriwayatkan hadis dengan redaksi tersebut. Dia menambahkan redaksi thumma lā ya'üdu (kemudian Nabi saw. tidak mengulangi mengangkat tangan lagi). ${ }^{14}$

Al-Shāfi'ì memilih hadis Salim dari ayahnya karena lebih kuat daripada riwayat al-Barā' bin 'Āzib. Al-Shāfi'ī menampilkan beberapa argumen untuk menguatkan riwayat Salim. Pertama, komentar Sufyān bahwa redaksi lā ya údu merupakan sisipan dari Yazīd, dan bukan dari al-Barā’ sendiri. Sisipan itu kemudian dianggap oleh rawi-rawi setelahnya sebagai bagian dari hadis, padahal bukan. Dengan demikian terdapat masalah dalam hafalan perawinya. Kedua, riwayat Salim dari ayahnya memiliki penguat dari generasi sahabat sebanyak sebelas orang. Hadis yang diriwayatkan sebelas orang harus lebih diutamakan daripada satu orang karena otentisitasnya lebih terjaga. Al-Shāfi ī menggunakan metode tarjīh al-riwāyah dalam menyelesaikan kontradiksi.

Tarjih dengan demikian merupakan upaya mengabaikan salah satu teks hadis karena adanya suatu pertimbangan eksternal yang berhubungan dengan otentisitas hadis.

Metode tarjih, untuk menyelesaikan kontradiksi, identik dengan metode nasakh. Dalam hal mengabaikan salah satu hadis yang dinilai kontradiksi.



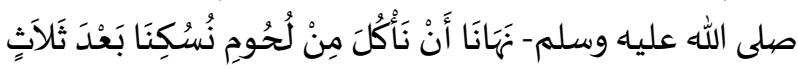

Dari Abū 'Ubayd yang berkata, "Aku menghadiri salat 'Id bersama 'Ali bin Abī Thalib. Beliau mengawali dengan salat sebelum khutbah dan berkata, 'Sesungguhnya Rasulullah saw. melarang kami memakan daging kurban kami setelah tiga hari."' 15 


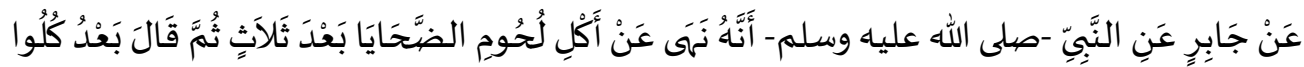



Dari Jābir dari Nabi saw. bahwa beliau melarang memakan daging kurban setelah tiga hari. Kemudian beliau mengatakan, "Makanlah, sisakan dan simpanlah." 16

Kedua hadis di atas mempunyai pengertian yang bertentangan. al-Imam Muslim menjembatani pertentangan itu dengan menggunakan konsep nasakh. Berdasarkan keterangan yang dimuat dalam hadis-hadis yang dicantumkannya dalam Bāb Bayān Mā Kāna min al-Nahy 'an Akli Lubūm al-Adhāhi ba'da Thalāthin fi Awwal al-Islām wa Bayān Nakhihi wa Ibāhatihi ilā Matā Shä’a (bab keterangan larangan memakan daging kurban setelah tiga hari pada masa awal Islam dan keterangan penghapusannya dan kebolehannya sampai kapan pun) bahwa larangan itu ditetapkan lebih dulu dan hadis yang membolehkan terjadi belakangan. Hal ini dibuktikan dengan perintah untuk mengambil bekal (tazawwadū) terjadi ketika Nabi saw. berhaji, yaitu tahun sepuluh hijriah.

Metode nasakh menyelesaikan problem kontradiksi dengan menganulir otoritas hadis yang dinilai lebih dahulu terjadi. Nasakh dibangun di atas dasar adanya informasi historis tentang mana di antara hadis yang terlebih dahulu terjadi dan mana yang lebih belakangan. Anulir ini penting dilakukan untuk mengeliminasi otoritas sebuah teks. Dengan mengabaikan intensi atau maksud dari pengujarnya (baca: Rasulullah saw.). Dalam ketiga praktik ini, interaksi hanya dilakukan antara seorang pembaca hadis dengan teks hadis itu sendiri. Dan mengabaikan intensi atau maksud dari si produsen hadis atau wacana.

\section{Gharīb al-Hadìth: Kasus Absurditas Makna dalam Teks Hadis}

Gharib al-Hadith menjadi studi yang bertujuan menjelaskan kosa kata matan hadis yang asing (absurd). Studi ini dibangun di atas asumsi adanya ketidakjelasan makna redaksi matan. Problem pokok dalam metode ini ialah bagaimana cara mencari kejelasan makna redaksi. Para ulama mengembangkan beberapa metode yang umumnya bersifat komparasi-intertekstual. Mekanismenya berkisar pada penggunaan logika induksi dari makna suatu sumber bahasa yang dianggap lebih jelas untuk kemudian diterapkan dalam kasus kebahasaan yang sedang dihadapi.

Metode ini dimulai dengan menelaah otentisitas redaksi teks yang sedang dikaji seperti dikembangkan oleh Abū 'Ubayd al-Qāsim bin Sallām dan Ibn alAthīr. Kemudian dilanjutkan pada perujukan pada sumber-sumber yang dinilai 
otoritatif seperti teks Alquran, hadis dan karya-karya sastra Arab (prosa maupun puisi). ${ }^{17}$

Penafsiran Gharīb dengan Alquran dapat dilihat dalam contoh berikut.

$$
\text { كان النبي يُقبِّل ويُبَاشر وهو صائم ولكنه كان أمْلَككم لأرَّبه }
$$

Nabi saw. mencium dan menyentuh saat berpuasa, tapi beliau lebih kuat menahan hasratnya di banding kalian. ${ }^{18}$

Abū 'Ubaid al-Qāsim bin Sallam mengartikan arabih dengan sesuai dengan QS. al-Nur: 31 yang berarti hasrat (kebutuhan kepada perempuan). ${ }^{19}$

Penjelasan redaksi gharīb juga bisa dilakukan dengan menggunakan hadis lain. Semisal penjelasan al-Khatthabi ketika menjelaskan hadis Abū Hurairah berikut ini. ${ }^{20}$

عن أبي هريرة قال : لما توفي رسول الله صلى الله عليه و سلم واستخلف أبو بكر بعده وكفر من



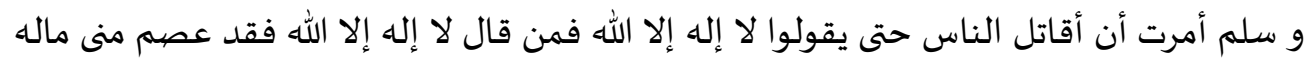

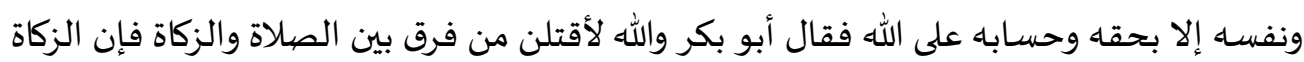

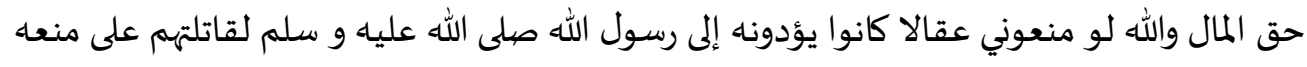

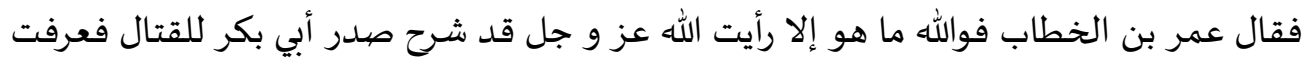
أنه الحق

Redaksi matan yang dianggap gharib ialah iqālan. Sebelum mengutarakan pendapatnya, al-Khatthabi menuturkan banyak pandangan yang dikembangkan ulama-ulama sebelumnya. Sebagian mengartikan iqälan dengan zakat harta selama setahun (shadaqat 'àm), jenis harta yang wajib dizakati seperti unta, sapi, kambing dan tumbuhan. Ada pula yang mengartikannya dengan tali (pengikat ternak). Dari keseluruhan pandangan tersebut, al-Khatthabi mendukung pendapat Muhammad bin Ibrahim bin Sa'id al-Abadi yang menyatakan bahwa arti iqälan adalah tali. Maksudnya adalah tali pengikat ternak. Hal ini merupakan kiasan bahwa mereka tidak mau membayar zakat sama sekali. Pengertian ini selaras dengan riwayat lain yang menggunakan redaksi 'anäqan dan jadyan (keduanya berarti anak kambing) sebagai ganti kata iqālan. Satu anak kambing pun mereka enggan membayarkannya. ${ }^{21}$ Seperti dalam riwayat al-Bukhari berikut ini.

والله لو منعوني عناقا كانوا يؤدونها إلى رسول الله صلى الله عليه و سلم لقاتلهم على منعها 
Penyelesaian gharīb dapat dilakukan dengan menggunakan riwayat lain yang semakna. Problem absurditas atau ketidakjelasan pengertian teks dalam konteks gharīb al-hadīth diselesaikan dengan merujuk teks lain yang dinilai memiliki penunjukan makna yang lebih terang. Di sini komparasi menjadi sebuah mekanisme yang wajib dilakukan dengan mengabaikan konteks hadis dan terlebih niatan pengujarnya.

\section{Asbäb al-Wurüd: Menjelaskan Absurditas Teks Berdasar Konteks}

Asbāb al-wurūd juga menjadi salah satu media memahami hadis Nabi saw. Bila dua metode sebelumnya menekankan pada pengertian redaksi, asbāb alwurūd lebih menekankan pada konteks kalimat (baca: wacana). Pendekatan asbab al-wurud tidak memiliki masalah dengan kontradiksi atau absurditas makna suatu kata. Masalah yang dihadapi pendekatan ini ialah fokus dan arah suatu pembicaraan. ${ }^{22} \mathrm{Hal}$ ini diselesaikan dengan melacak latar belakang kemunculan suatu hadis. Semisal hadis tentang niat berikut ini.

علقمة بن وقاص قال سمعت عمر بن الخطاب رضي الله عنه يخطب قال سمعت النبي صلى الله

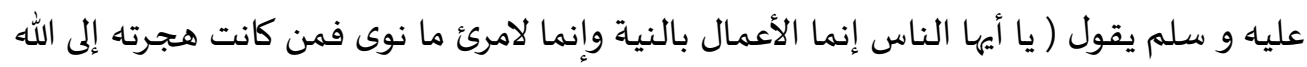

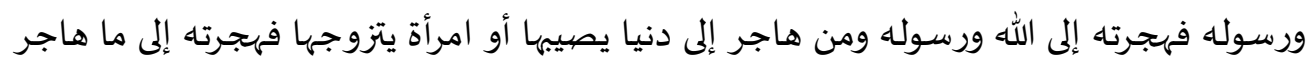

Dari 'Alqamah bin Waqqās yang berkata, "Aku mendengar 'Umar bin alKhatthab r.a. berkhutbah. Dia berkata, 'Aku mendengar Nabi saw. bersabda, 'Wahai manusia! Amal-amal ditentukan niatnya. Bagi setiap orang apa yang diniatkannya. Barang siapa berniat hijrah kepada Allah dan rasuln-Nya, maka hijrahnya kepada Allah dan Rasul-Nya. Barang siapa berhijrah kepada dunia yang akan dia dapatkan, atau perempuan yang akan dinikahinya, maka hijrahnya kepada apa yang diniatkan dalam hijrahnya. ${ }^{23}$

Secara redaksional hadis di atas tidak memiliki masalah. Namun ketika narasi itu dipertanyakan, dalam konteks apa Rasulullah saw. menyampaikan khutbahnya tersebut, serta kepada siapa Rasulullah saw. menujukannya, lalu mengapa beliau perlu menyebut kata dunyā atau imra'ah? Adakah alasan pemilihan diksi tersebut? Pertanyaan ini muncul ketika kita mengharapkan makna yang dikehendaki Nabi saw. Hal ini berbeda dengan bila kita mencukupkan diri dengan pengertian yang diperoleh secara tekstual. ${ }^{24}$ Kemudian dilakukan transendensi teks (melepaskannya dari konteks kesejarahannya), maka tidak perlu ada pertanyaan tentang itu. Pertanyaanpertanyaan di atas merujuk kepada konteks hadis yang hanya bisa dijawab melalui informasi yang dilaporkan saat itu. Para ulama menegaskan bahwa 
asbāb al-wurūd -seperti asbāb al-nuzūl bukanlah suatu konsep yang bisa direkareka melalui mekanisme qiyas atau ijtihad. Ia harus didasarkan pada sejarah (history). Karenanya ia hanya bisa bersumber dari riwayat dan $\operatorname{sim}^{-} \cdot{ }^{25}$

Ibn Hamzah al-Dimasyqī meriwayatkan dua buah hadis tentang asal usul hadis tersebut. Salah satunya terkait dengan seseorang yang ikut berhijrah bukan karena menaati perintah Allah dan Rasul-Nya, tapi karena hendak menikahi seorang perempuan. Sahabat tersebut akhirnya dikenal dengan sebutan Muhajir Ummu Qays. ${ }^{26}$ Di sinilah kita mendapatkan jawaban untuk merespon apa dan kepada siapa sebenarnya hadis itu ditujukan. Dengan demikian, asbab al-wurud merupakan upaya untuk menjawab absurditas wacana yang terkandung dalam hadis. Asbab al-Wurud dapat diketahui melalui perbandingan riwayat (muqāranah al-riwāyah). Di sini, takhrīj al-ḩadīth menjadi penting untuk menemukan riwayat-riwayat yang sama dan saling melengkapi. Studi tentang konteks kemunculan hadis ini menjadi metode yang berbeda dengan dua metode sebelumnya yang menekankan pada aspek internal teks. Metode ini mencoba memasuki wilayah di luar teks hadis (pernyataan Nabi saw.), sekalipun masih bertumpu pada matan hadis dan tentu saja data yang berbentuk teks. Namun asbāb al-wurūd menambahkan pentingnya konteks pembicaraan. Kekurangan satu-satunya dari metode asbāb al-wurūd adalah tiadanya visi untuk mengeksplorasi tujuan Nabi saw. lebih jauh. Perhatian terhadap intensi Nabi saw. ketika menyatakan suatu perkataan terabaikan begitu saja dalam konteks pembacaan asbāb al-wurūd. Selain itu, asbāb al-wurūd masih sangat tergantung pada teks matan hadis. Dari dua premis terakhir ini, penulis mengamati bahwa asbāb al-wurūd sekalipun menaruh perhatian di luar teks an sich namun pengabaiannya terhadap intensi Nabi saw. dan konstruksi sosial yang turut membentuk dan mempengaruhi statemen-statemen Nabi saw. tidak digarap begitu dalam. Hal ini seperti dapat ditemukan dalam kitab-kitab yang bergenre asbāb al-wurūd yang hanya mencantumkan riwayat tidak ubahnya seperti kitab matan hadis.

Secara ringkas, metode-metode pemahaman hadis yang dikembangkan melalui tiga studi ilmu matan hadis dapat digambarkan sebagai berikut. 
Peta Konsep Problem Ilmu Matan Hadis

\begin{tabular}{|c|c|c|}
\hline Metode & $\begin{array}{c}\text { Asumsi } \\
\text { Problematik }\end{array}$ & Penyelesaian \\
\hline \multirow{3}{*}{$\begin{array}{l}\text { Mukhtalif al- } \\
\text { Hadith }\end{array}$} & \multirow[t]{3}{*}{ Kontradiksi } & al-jam' \\
\hline & & naskh \\
\hline & & tarjih \\
\hline \multirow[t]{3}{*}{ Gharīb al-Hadīth } & \multirow{3}{*}{$\begin{array}{l}\text { Ketidakjelasan } \\
\text { makna kata }\end{array}$} & Merujuk Alquran \\
\hline & & Merujuk Hadis \\
\hline & & Merujuk Syair Arab \\
\hline Asbāb al-Wurūd & $\begin{array}{l}\text { Ketidakjelasan } \\
\text { pengertian/wacana/ } \\
\text { fokus kalimat }\end{array}$ & $\begin{array}{l}\text { Melakukan perbandingan riwayat } \\
\text { (muqāranah al-riwāyah) }\end{array}$ \\
\hline
\end{tabular}

Tabel di atas menunjukkan kepada kita tentang keragaman problem pemahaman matan hadis Nabi saw. yang dihadapi pembaca berikut cara-cara menyelesaikannya. Tiga problem pokoknya meliputi kontradiksi, absurditas makna dan absurditas konteks. Sedangkan cara penyelesaiannya berkisar pada penggunaan kaidah kebahasaan dan perbandingan riwayat. Kecuali dengan as $\bar{a} \bar{b}$ al-wurūd, pembaca hadis sering kali lebih memfokuskan diri pada teksteks hadis daripada konteks bahkan pengujar hadis itu sendiri. Ini berbeda dengan pembacaan asbäb al-wurüd yang masih peka terhadap konteks. Sekalipun demikian, metode asbäb al-wurüd bukan tanpa celah. Metode ini hanya berbicara tentang mengapa Nabi mengatakan sesuatu, dalam kondisi seperti apa dan kepada siapa. Namun yang diabaikan di sini ialah apa tujuan beliau menyatakan suatu pernyataan, dalam posisi apakah Nabi saw. saat menyabdakan sabda-sabdanya. Apa tujuan sabda itu? Berdasar kapasitas sebagai apa beliau bersabda? Perintah agama, anjuran atau kebijakan sosial-politikkah? Inilah yang tidak dijawab oleh metode asbāb al-wurüd. Ketiga metode tersebut pada prinsipnya masih berkutat pada hal-hal di luar diri Nabi saw. (bersifat eksternal). Dan cenderung memfokuskan diri pada teks, sehingga seakan-akan teks itu berdiri sendiri terlepas dari pemiliknya. Seorang pembaca hanya akan sibuk mengkomparasikan antar teks seraya mengabaikan fokusnya pada subjek bahasa. Di sini terjadi apa yang dalam kritik wacana disebut positivisasi bahasa. Pemilik teks dilupakan dan kita percaya pada teks seakan dia bisa merepresentasikan pemiliknya secara objektif. Cara pandang ini tentu 
melupakan kesadaran, serta kehendak personal subjek (pemilik teks). Dari analisis ini dapat dikatakan bahwa ilmu matan hadis didasarkan kepada, meminjam model analisis wacana, paradigma positivis. Yaitu model pembacaan teks yang hanya tertumpu pada teks dengan melupakan intensi atau motif produsen wacana.

Diagram Skematik Wacana Ilmu Matan Hadis

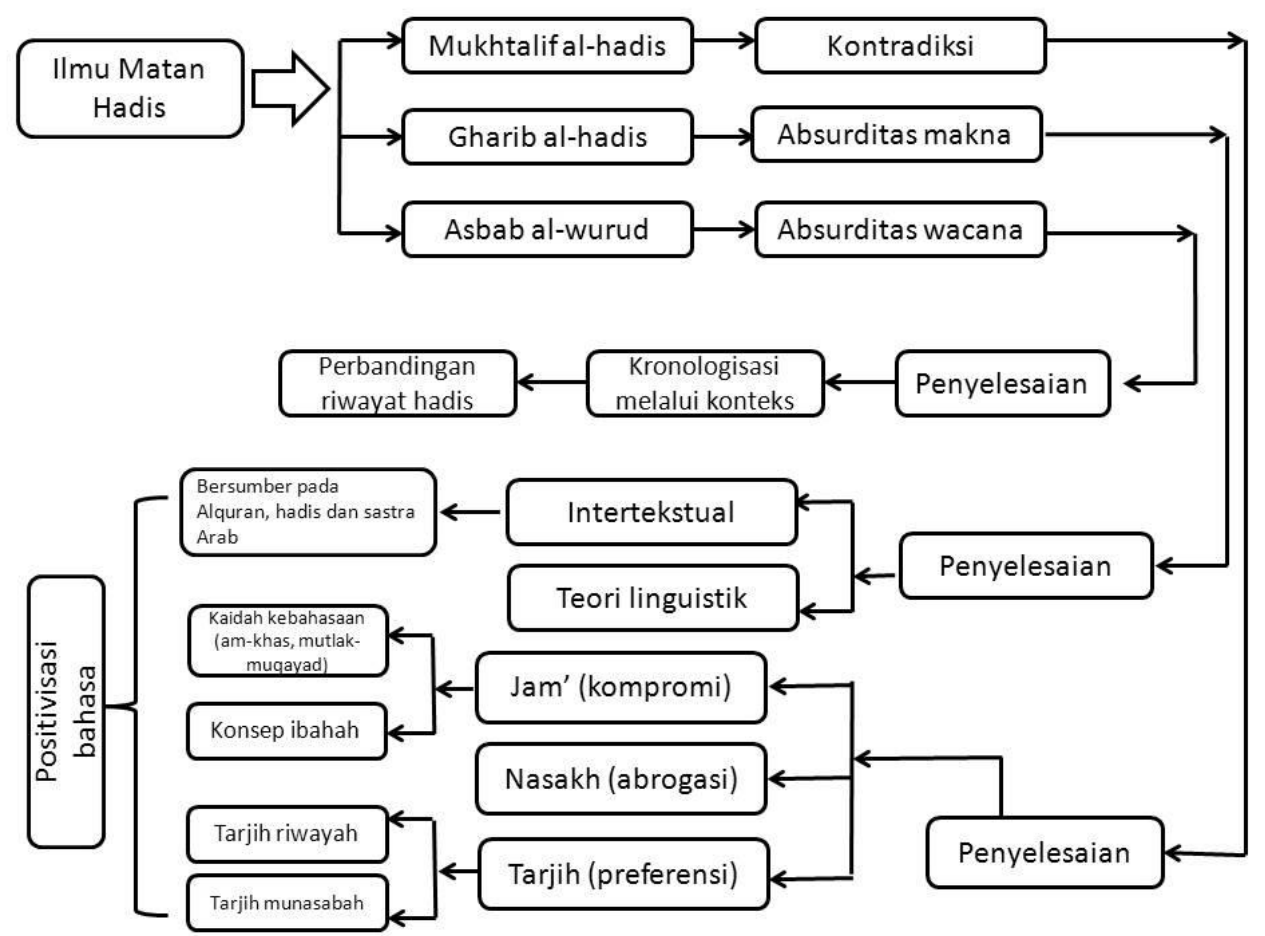

Problem semacam inilah yang hendak diselesaikan cara baca diferensiasimaqāṣidī yang menekankan pentingnya intensi (tujuan/maksud) personal Nabi saw. Cara baca ini mengajak kita memahami hadis melalui pendekatan subjek itu sendiri. Di sisi lain, keterbelengguan dalam kecenderungan kebahasaan merupakan tanda bahwa pendekatan yang digunakan dalam memahami hadis selama ini cenderung positivistik. Yaitu, suatu pengamatan wacana yang percaya pada kebenaran bahasa sehingga untuk mendapatkan kebenaran harus mengacu kepada telaah-telaah kebahasaan itu sendiri. Dalam perspektif paradigma analisis wacana, proses pemahaman teks semacam ini tergolong ke dalam analisis wacana berparadigma positivis. 


\section{Pembacaan Maqāșid Ibn 'Āshūr; Model Paradigma Konstruktivis}

Ibn 'Āshūr adalah ulama kelahiran Tunisia pada tahun 1296 H./1879 M. Dia bernama lengkap Muhammad al-Ṭāhir ibn 'Āshūr. Dia mengawali pendidikannya pada umur enam tahun dengan menghafal Alquran, menulis dan belajar bahasa Perancis ${ }^{27}$ di Masjid Agung Tunis. Pada 1310 H., saat umurnya empat belas tahun, dia berhasil lolos tes masuk Zaitūnah. Zaitūnah merupakan perguruan tinggi yang masih menerapkan sistem tradisional seperti sistem ijäzah, sanad, serta ilmu-ilmu keislaman yang berbasiskan kitab kuning dengan semua tingkatannya. Ibn 'Āshūr menyelesaikan pendidikannya tujuh tahun kemudian. Yaitu pada tahun 1317 H./1899 M. Saat umurnya menginjak 21 tahun. Setelah itu dia mengabdi di almamaternya dan karirnya terus melonjak. Jabatan terakhirnya adalah hakim agung dan rektor Universitas Zaitunah. Dia meninggal pada tahun 1973 M. ${ }^{28}$

Ibn 'Āshūr mengenal ide-ide maqūṣid al-sharī'ah dari dua sumber. Pertama, Muhammad 'Abduh yang telah menemukan manuskrip kitab al-Muwāfaqāt karya al-Shāțibī. Muhammad 'Abduh menganjurkan murid-muridnya agar mengedit dan menerbitkannya. Buku itu akhirnya diedit oleh 'Abdullāh Darrāz, murid 'Abduh. ${ }^{29}$ Penerbitan dalam bentuk buku cetak pertama kali dilakukan di Tunisia. ${ }^{30}$

Kedua, Universitas Zaitūnah memoderniasi diri di antaranya dengan terbitnya jurnal ilmiah. Tujuannya adalah mendinamisasi perkembangan keilmuan. Jurnal Zaitūnah, suatu ketika mempublikasikan laporan penelitian mengenai maqūsid al-sharī'ah karya Syaikh Muhammad al-'Azīz Ju'aid (18861970 M.). Kawan sejawat Ibn 'Āshūr ini mendorong para ulama Zaitūnah mengembangkan kajian maqāsid al-sharī'ah. Menurutnya, Usul Fikih yang berfungsi sebagai alat untuk memahami teks-teks sumber Islam menemukan tantangan yang berat karena dianggap gagal menjawab problem-problem modernitas. 'Azīz Ju'aid menyarankan "kodifikasi” studi maquạis yang sampai saat itu masih tercecer dalam teks-teks khazanah keilmuan Usul Fikih. ${ }^{31}$

Ibn 'Āshūr menanggapi seruan tersebut dan menulis sebuah buku tentang maqūsid al-sharīa'ah. Secara rutin, Ibn 'Āshūr mengajarkan kitab Maquạiid alSyarīah al-Islämiyyah karyanya bersama dengan al-Muwäfaqāt kepada mahasiswa-mahasiswanya. Di kemudian hari, kitab Maquasid al-Sharīah alIslamiyyah tersebut menjadi referensi utama bersamaan dengan peresmian diskursus maqūsid al-sharīah sebagai mata kuliah Universitas Zaitūnah. Langkah ini kemudian diikuti oleh universitas Islam lainnya di belahan negaranegara Islam di wilayah Afrika Utara. ${ }^{32}$ Buku Maqāsid al-Sharī'ah al-Islāmiyyah mendapat apresiasi dari para ulama. ${ }^{33}$ Bagi Ibn 'Āshūr, maqāsid al-sharī'ah 
sangat penting dikembangkan sebagai pelengkap ilmu Usul Fikih. Dalam batasan tertentu, ia menyatakan perlunya pemisahan keduanya. Maquașid alShari'ah harus menjadi ilmu yang berdiri sendiri, ${ }^{34}$ bersanding dengan ilmuilmu syariah lainnya. Maqāsid al-sharī'ah merupakan bidang studi yang sangat dibutuhkan oleh ahli hukum Islam (ihtiyāj al-faqīh ilā ma'rifat maquașid alshari'ah). ${ }^{35}$

Ibn 'Āshūr mendefinisikan maqūṣid al-sharī'ah sebagai nilai kearifan yang menjadi acuan dalam perumusan aturan Islam. ${ }^{36}$ Dalam konteks ini, syariat berarti aturan Islam yang terdapat dalam Alquran dan hadis. Maqāṣid berarti tujuan-tujuan. Bila digabungkan, arti maqūsid al-sharī'ah berarti tujuan-tujuan aturan yang terdapat dalam Alquran dan hadis. Tujuan-tujuan dari aturan itu berupa nilai-nilai yang hendak diwujudkan melalui pelaksanaan aturan tersebut. ${ }^{37}$

Ibn 'Āshūr menyatakan teks-teks syariat tidak cukup hanya dipahami pengertian tekstualnya, apalagi dengan mengabaikan tujuan dari aturan syariat itu sendiri. Menganalisis teks-teks syariat secara tekstual -seperti dilakukan dalam Usul Fikih, juga tidak akan mengantarkan kepada nilai yang menjadi tujuan pembuatan aturan syariat (adillat al-sharì'ah al-lafziyyah là tastaghnì 'an ma'rifat al-maqāsid al-shar'iyyah). Karena, menurutnya, bahasa apapun yang dikenal peradaban manusia memiliki keterbatasan-keterbatasan dalam menyampaikan suatu pesan kepada pendengarnya. Distorsi makna sangat lazim menghampiri proses komunikasi kebahasaan. Bahkan distorsi itu timbul dari internal bahasa itu sendiri karena tingkat kejelasan makna suatu kata yang bertingkat-tingkat berikut strukturnya yang sering mengaburkan kehendak sejati pengujarnya. ${ }^{38}$

Ibn 'Āshūr menyatakan bahwa ketepatan pemahaman seorang mujtahid sangat dibutuhkan untuk perumusan hukum syariat (tasyrī $)$. Dalam konteks perumusan hukum syariat berdasarkan hadis misalnya, pengetahuan mengenai posisi Nabi saw. wajib diketahui terlebih dahulu. Apakah suatu pernyataan Nabi muncul untuk tujuan tasyrī atau bukan. Di sini, mengetahui posisi Nabi saw. menjadi penting. Dia mengeritik sebagian fukaha yang hanya mengandalkan analisis bahasa dan mengesampingkan konteks serta motif pensyariatan. ${ }^{39}$ Padahal, mayoritas ulama telah mencontohkan tradisi yang baik dalam mengenali konteks dan motif suatu sabda Nabi saw. dengan mengunjungi Mekah dan Madinah untuk melihat secara langsung bagaimana kira-kira praktik Nabi saw. dulu, dan seperti apa yang dipraktikkan pengikutnya yang setia. ${ }^{40}$ Melihat konteks dapat membantu kita menemukan tujuan syariat. ${ }^{41}$ 
Dalam konteks ini, pemahaman Ibn 'Āshūr terhadap hadis merupakan bagian dari pemahaman dalam kerangka maqūsid al-sharī'ah. Ibn 'Āshūr berangkat dari maqāṣid al-sharīah kemudian berupaya mengembangkan konsep maquasid al-hadìth dan lebih dengan proyek diferensiasi posisi Nabi saw., Ibn 'Āshūr berupaya membongkar maqāșid al-nabì. Di sinilah terjadi pertemuan antara diskursus maqāsid al-sharíah dengan diferensiasi posisi Nabi saw. Diferensiasi merupakan jalan menemukan maqūsid al-sharì ah yang dalam arti sempit mencakup hadis-hadis Nabi saw. Di sisi lain, pemilahan posisi menjadi strategi untuk menilai apakah sebuah hadis (pernyataan Nabi) dapat dinilai bermuatan hukum syariat (tashrī $\left.{ }^{-} \bar{\imath}\right)$ atau tidak (al-ghayr al-tashrī $\left.\bar{\imath}\right)$. Di sini kemudian dapat disimpulkan tidak semua hadis bertujuan tashrit sehingga tidak semua wajib diikuti tanpa terlebih dahulu diketahui motif pernyataan Nabi saw. Dalam konteks ini, dapat diketahui perbedaan model pemahaman hadis Ilmu Matan Hadis yang mengabaikan intensi dan motif sabda Nabi saw. dengan model pemahaman maqāṣidī Ibn 'Āshūr yang secara teknis dilakukan dengan memilah-milah posisi Nabi saw. Perhatian dalam proses pemahaman hadis tidak hanya ditujukan kepada problem teks, tapi juga diarahkan kepada pentingnya analisis terhadap produsen wacana atau teks. Inilah yang tidak ditemukan dalam analisis wacana model Ilmu Matan Hadis.

Alur pemikiran diferensiasi Ibn ‘Āshūr

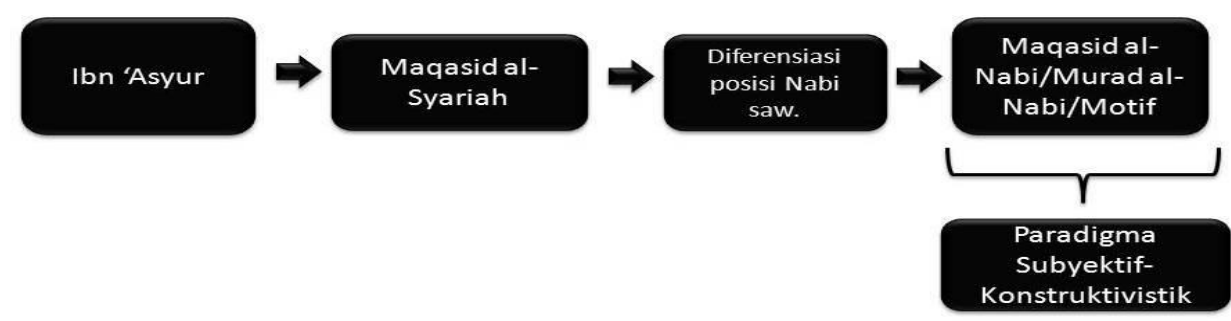

\section{Metode Rekonstruksi Maqāsid al-Nabī}

Ibn 'Āshūr membahas topik pemilahan peran atau posisi Nabi saw. dalam bab intisăb al-shāri ' li al-tashrī' (peran Nabi dalam pembentukan syariat). Dia menyatakan,

"Seorang pengkaji maqūșid al-sharì'ah harus memperhatikan perbedaan posisi ucapan dan perbuatan Rasulullah. Dan dia harus mampu memilah beragam bentuk perilaku/kebijakan beliau. Rasulullah saw. mempunyai beragam latar belakang peran sosial yang selayaknya menjadi motif ucapan dan perbuatannya. 
Pengkaji maqūsid al-sharì'ah sangat memerlukan pengetahuan tentang motif yang mendasari keduanya." ${ }^{42}$

Inilah kaitan antara maqāṣid dengan pemilahan peran Nabi saw. dalam pemikiran Ibn 'Āshūr. Ibn 'Āshūr mengakui bahwa dirinya bukan orang yang pertama kali menyadari konsep ini. Menurutnya, orang yang pertama kali memperkenalkannya adalah Shihāb al-Dīn Ahmad bin Idrīs al-Qarrāfĩ dalam kitab Anwā' al-Burūq fì al-Furūq. Ibn 'Āshūr mengatakan,

"Orang yang pertama kali mendapat petunjuk memikirkan perbedaan dan pentingnya penentuan (latar belakang yang menjadi motif) adalah al-'Allämah Syihāb al-Dīn Ahmad bin Idrīs al-Qarrāfī dalam kitab-nya, Anwā' al-Burūq fì al-Furūq. Dia mengulas perbedaan itu pada bab ke-36 mengenai kaidah kebijakan Rasulullah sebagai putusan hukum (al-qad̄̄) kaidah kebijakan beliau dalam bentuk fatwa (al-fatwā), dan kaidah kebijakan beliau dalam kapasitasnya sebagai pemimpin politik (al-imämah)." ${ }^{43}$

Teks di atas menunjukkan bahwa al-Qarrāfī memperkenalkan tiga peran Nabi saw. selain perannya sebagai penyampai risalah Tuhan (tabligh al-Risälah).


(al-imämah). Pernyataan Nabi saw. yang lahir dari masing-masing peran memiliki implikasi yang berbeda. Hanya saja, al-Qarrafi tidak menjelaskan lebih lanjut mengenai dasar pemilahan yang dibuatnya. Bahkan, al-Qarrafi berlanjut pada penjelasan mengenai implikasi dari ketiga posisi Nabi tersebut. Bahwa sabda yang disampaikannya dalam konteks tabligh al-risälah wajib diikuti oleh seluruh umat Islam hingga kiamat kelak. Bila pernyataan itu berbentuk perintah, maka setiap orang wajib melaksanakannya. Begitu pula bila mubah. Setiap orang boleh melakukan atau meninggalkan. Bila pernyataan itu berbentuk instruksi (perintah), setiap orang wajib menjauhinya. ${ }^{44}$

Hal ini berbeda dengan pernyataan Nabi saw. yang muncul dalam kapasitas beliau sebagai pemimpin politik (al-imāmah). Menurut al-Qarrāfî, setiap orang tidak boleh melakukannya tanpa persetujuan politik dari seorang pemimpin. Karena motif kebijakan tersebut didasarkan pada asumsi kepemimpinan, bukan tabligh al-risälah. ${ }^{45}$

Pernyataan Nabi saw. yang muncul dalam konteks memberi putusan hukum atas suatu persoalan, berimplikasi pada ketidakbolehan setiap orang melakukannya kecuali atas wewenang yang didasarkan pada putusan hakim. ${ }^{46}$

Pembedaan-pemilahan (diferensiasi) posisi Nabi saw. yang berimplikasi pada perbedaan materi pemahaman yang dihasilkan dalam penalaran hadis di atas di bangun di atas asumsi maqāsid al-Nabì (motif Nabi). Motif Nabi saw. sendiri dibatasi pada tiga peran beliau saat itu. Al-Qarrāfì mengenalkan tiga 
peran itu adalah hakim, mufti dan imam. Ibn 'Āshūr tidak berhenti sampai di situ. Dia mengembangkan posisi-posisi Nabi saw. lebih luas. Dalam pernyataannya dia mengatakan, "Rasulullah saw. mempunyai sifat-sifat (identitas) dan keadaan-keadaan (kondisi-kondisi) yang menjadi motif ucapan dan tindakan beliau. Maka menjadi kewajiban kita menyalakan lentera yang dapat menjadi penerang dalam banyak persoalan yang menyulitkan manusia dan memecah belah pikiran mereka. Para sahabat membedakan perintahperintah Rasulullah yang muncul dalam konteks pembuatan hukum syariat (legislation) dan yang bukan dalam rangka legislasi. Ketika suatu ucapan beliau dinilai belum jelas dalam pandangan mereka (dalam rangka tashri ${ }^{r}$ atau bukan) mereka bertanya kepada Nabi saw. ${ }^{47}$

Bagian terakhir teks Ibn 'Āshūr tersebut menunjukkan adanya praktikpraktik diferensiasi yang dilakukan para sahabat. Di antaranya dapat ditemukan dalam hadis Barirah, budak yang dimerdekakan 'Āishah serta menolak kembali kepada suaminya, ${ }^{48}$ dan hadis Jabir tentang utang bapaknya yang telah meninggal. ${ }^{49}$ Kedua hadis ini intinya penolakan sahabat terhadap sebagian perintah Nabi saw. karena motif (alasan yang mendorong Nabi mengeluarkan pernyataan) bukan dalam konteks agama. Inilah yang bukti yang digunakan Ibn 'Āshūr bahwa para sahabat telah melakukan diferensiasi posisi Nabi saw.

Pemilahan posisi-peran Nabi saw. dalam konteks pemahaman hadis merupakan isu lama yang menemukan momentumnya bersamaan dengan dikembangkannya diskursus maqūṣid al-sharī'ah. Di awali oleh al-Qarrāfì alMālikī (684 H.), ulama mazhab Malikī yang juga murid al-'Izz bin 'Abd alSalām al-Shāfi'ī (660 H.), yang mulai menyadari keragaman peran Nabi saw. Baginya kesadaran keragaman peran itu penting untuk mengetahui peran-motif sabda beliau. Perbedaan peran-motif berimplikasi pada perbedaan tingkat otoritas sabda, sejauh mana pesan hukum yang dikandungnya terhadap ketaatan umat terhadapnya. Motif inilah yang disebut oleh Ibn 'Āshūr dengan terma $b \bar{a}{ }^{-} i t h^{50}$ dan murād al-nabis ${ }^{-51}$ atau maqūșid al-ras $\left.\bar{u}\right|^{2}$ dalam bahasa Jasser Audah. Peran dan motif itu secara lebih jelas berupa sifat-sifat (sifät) dan kondisi-konsisi $(a h w \bar{a} l) .{ }^{53}$ Dari sini, jelaslah bahwa pembacaan diferensiasif diperlukan untuk mengungkap motif Nabi saw.

Perlu diketengahkan pula bahwa sekalipun al-Qarrāfī mencanangkan pembacaan diferensiasif, namun beliau tidak tegas menjelaskan hubungannya dengan maqūsid al-sharī'ah. Hal ini baru dinyatakan oleh Ibn 'Āshūr pada abad modern. Dia adalah tokoh yang pertama kali mengkampanyekan adanya hubungan strategis antara maqāsid al-sharī'ah dengan diferensiasi. ${ }^{54}$ 


\section{Metode Pemilahan}

Seperti dipaparkan sebelumnya, Ibn 'Āshūr berhutang pada al-Qarrāfī dalam konsep diferensiasinya. Dan Ibn 'Āshūr menegaskan pentingnya diferensiasi ini untuk menemukan maqāsid al-sharī ah dari suatu hadis Nabi. alQarrāfì sendiri hanya berhasil mengungkap tiga macam kategori peran Nabi. Proyek ini dilanjutkan oleh Ibn 'Āshūr dengan mengembangkannya menjadi dua belas kategori. Dua belas kategori itu meliputi; al-tashrī' (pembentukan syariat agama), al-fatwā (pemikiran/opini agama), al-qad̄a' (putusan hukum), al-imārah (keputusan politik), al-hadyu (petunjuk), al-șulh (kontrak damai), ishärah 'alā al-mustashīr (pertimbangan), al-nașihah (saran), takmīl al-nufüs (penguatan mental), ta 'lìm haqà̃ iq al-'äliyyah (pengajaran nilai-nilai luhur), alta'dìb (pendidikan pekerti), al-tajarrud 'an al-irsyād (pernyataan tanpa motif tertentu). ${ }^{55}$

Kedua belas kategori secara esensi dapat disederhanakan ke dalam tiga kecenderungan; teologis (tasyrī' dan fatwā), sosiologis (imārah, qad $\bar{a}$ ', hadyu, șulh) dan etis (musālahah, isyārah, nașīhah, takmīl. ta 'lìm, ta'dīb, tajarrud). Hal ini menunjukkan tiga tugas kehadiran para rasul di muka bumi. Mereka mempunyai tanggung jawab meluruskan keyakinan terhadap Tuhan di kalangan umat manusia, menyelesaikan problem-problem sosial umat mereka dan mengajarkan etika kepada mereka agar dapat menjalani kehidupan dengan baik.

Diagram 2. Kategorisasi Posisi Nabi saw.

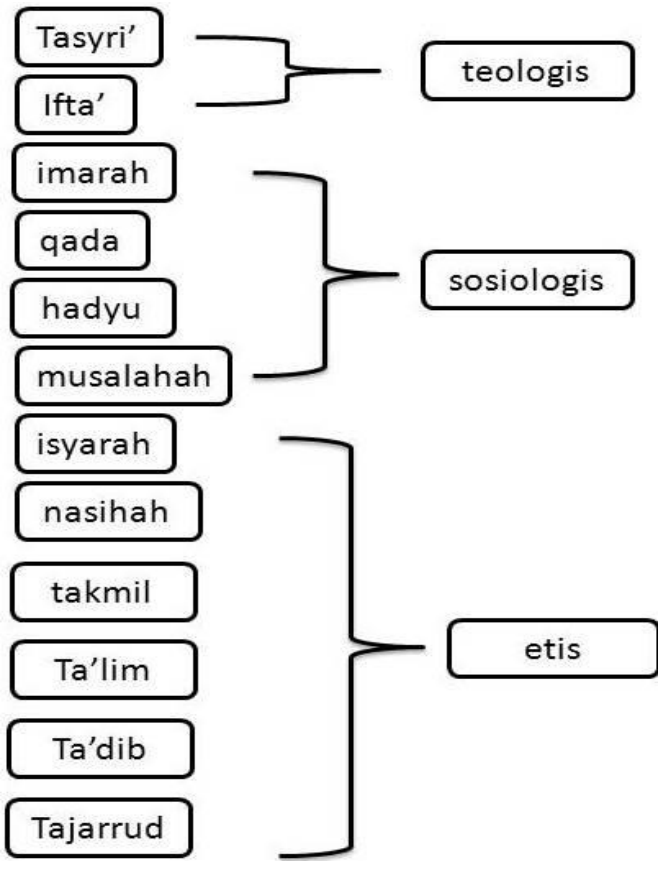


Sedangkan diferensiasi peran Nabi dilakukan berdasarkan indikator (qarä’in). Bila tidak ada indikator maka sebuah teks hadis harus diposisikan dalam konteks legislasi (tashrī $).{ }^{56}$

\section{Sistem Indikator}

Ulasan sebelumnya menunjukkan peran penting indikator dalam proses pemilahan posisi Nabi saw. Bahkan sejak awal, Ibn 'Āshūr telah menyatakan pentingnya apa yang disebutnya al-sifat wa al-ahwal. Setidaknya, ada dua model indikator yang digunakan Ibn 'Āshūr. Yaitu indikator internal dan indikator eksternal.

Indikator internal adalah indikator yang terdapat dalam matan (teks) hadis. Hal ini dapat dilihat misalnya penggunaan kata iqdi bainana (berilah kami putusan hukum), laaqdiyanna bainakuma (aku akan memberi putusan hukum pada kalian berdua) dan ikhtasama (keduanya berseteru) dan penggunaan redaksi nahani (dia melarang saya) yang disandingkan dengan redaksi nahana (dia melarang kami). Indikator internal ini banyak digunakan Ibn 'Āshūr dalam menentukan peran Rasulullah saw.

Sedangkan indikator eksternal merupakan model indikator yang berada di luar teks matan hadis. Ibn 'Āshūr menyebutkan dua buah contoh, yaitu pendapat sahabat dan pendapat para ulama. Di bawah ini, penulis akan menunjukkan penggunaan indikator tersebut dalam proses pemilahan peran Nabi saw. serta implikasi dari proses pemilahan tersebut.

\section{Contoh-Contoh Pemilahan}

\section{1. al-tasyrī' (pembentukan syariat agama)}

Kategori pertama yang ditemukan Ibn 'Āshūr ialah tasyrì' atau pembuatan hukum, kaidah-kaidah dan aturan agama berdasarkan wahyu Tuhan. ${ }^{57}$ Ibn 'Āshūr menyatakan bahwa peran ini merupakan yang paling banyak melatarbelakangi pernyataan-pernyataan Rasulullah. Alasannya, tashri ‘ merupakan sifat dasar yang dimiliki Nabi saw. berdasarkan firman Allah,

$$
\begin{gathered}
\text { "Muhammad itu tidak lain hanyalah seorang rasul..." } \\
\text { (QS. Ālu 'Imrān: 144) }
\end{gathered}
$$

Rasul ialah utusan Tuhan yang bertugas menyampaikan risalah (pesan Tuhan) kepada umat manusia. Dimensi tasyrī' Rasulullah saw. didasarkan pada peran beliau sebagai penyampai pesan Tuhan (tablīgh al-risālah). Posisi ini tentu saja menegasikan peran-peran beliau yang lain seperti mufti atau pemimpin 
politik yang mendasarkan diri pada sumber hukum, dimana kedua posisi itu mengandaikan keterlibatan sisi intelektual-kuasa manusiawinya dalam memahami sumber hukum (baca: wahyu). Posisi sebagai pembuat syariat (syāri) melepaskan diri beliau sebagai manusia yang sadar (memiliki kehendak dan rasional), dan hanya menampilkan sisi risalahnya saja. Dari sini, kita dapat membedakan antara peran sebagai pembuat syariat (syāri') dan mufti maupun imam.

Pertanyaanya, bagaimana cara mengidentifikasi posisi tasyrì $i$ ini dalam hadis? Sebagai teks mati yang tidak dapat menjelaskan dirinya sendiri, bagaimana seseorang bisa mengetahui bahwa suatu hadis muncul dalam kapasitas beliau sebagai rasul atau lainnya?

Tidak banyak jawaban yang dapat ditemukan dalam teks Ibn 'Āshūr selain bahwa hal itu dapat diidentifikasi melalui indikator-indikator (qarä’in). Tepatnya indikator bahwa bahwa maksud Rasulullah adalah membentuk syariat (qarā’in al-intișāb li al-tashrī). Indikator dapat berbentuk situasi penyampaian pesan beliau kepada umatnya. Hal ini dapat dilihat dalam hadis berikut.

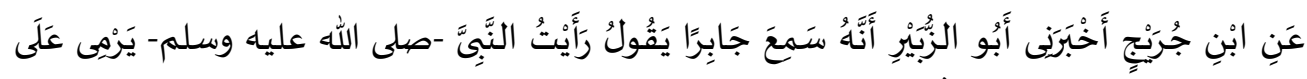

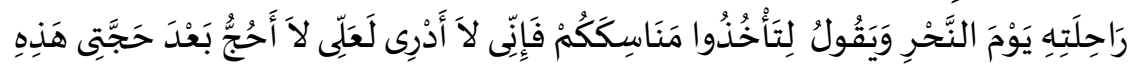
“Dari Ibn Juraij, dari Abū al-Zubair bahwa dia mendengar Jābir berkata, “Saya melihat Nabi saw. melempar jamrah melalui atas kendaraan pada hari nahar (idul adha) dan bersabda, 'Ambillah manasik kalian (dariku) karena aku tidak tahu mungkin aku tidak akan bisa berhaji lagi setelah hajiku yang sekarang (haji wida')." (HR Muslim)

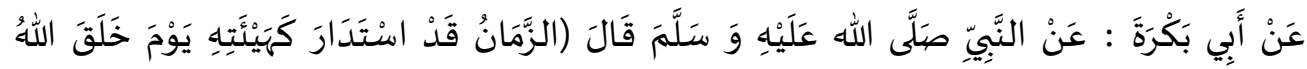



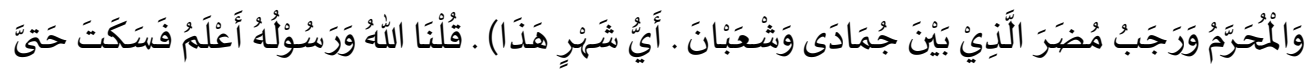

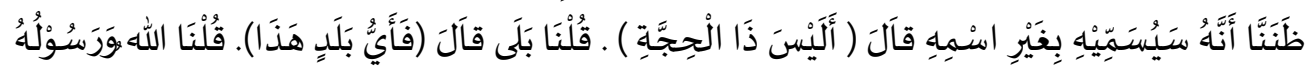



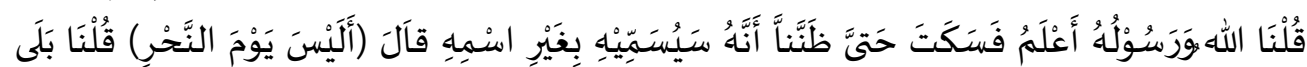

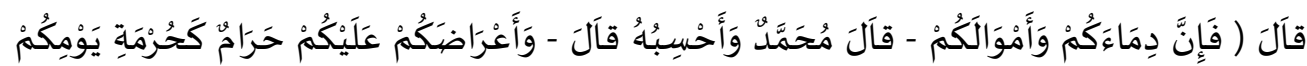



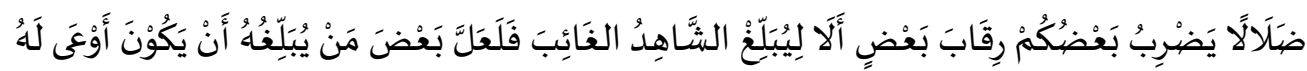
مِنْ بَعْضِ مَنْ سَمِمَهُهُ 
Dari Abū Bakrah, dari Nabi saw. beliau bersabda, "Zaman berputar sebagaimana keadaan di hari Allah menciptakan langit dan bumi. Satu tahun berjumlah dua belas bulan. Empat di antaranya adalah bulan suci (asyhur burum) yang tiga bulan muncul berturut-turut; Zulqa'dah, Zulhijjah, Muharram dan Rajab Mudhar yang berada di antara bulan Jumada dan Sya'ban. Sekarang bulan apa?" Kami menjawab, "Allah dan Rasul-Nya lebih mengetahui." Beliau terdiam hingga kami mengira beliau akan memberi nama selain namanya. Nabi saw. bersabda, "Bukan kah ini bulan Zulhijjah?” Kami menjawab, "Benar." Nabi saw. bertanya, "Negeri apa ini?" Kami menjawab, "Allah dan Rasul-Nya yang lebih mengetahui." Beliau diam hingga kami mengira beliau akan menamai dengan selain namanya yang sekarang. "Bukan kah ini negeri (Haram)?” Kami menjawab, "Ya." Nabi saw. bertanya lagi, "Hari apa ini?" Kami membalas, "Allah dan Rasulullah lebih mengetahui." Beliau diam hingga kami mengira beliau akan memberi nama selain namanya. Nabi saw. bersabda, "Bukankah hari nahar?" kami menjawab, "Ya." Beliau melanjutkan, "Sesungguhnya darah kalian, harta kalian -Muhammad perawi berkata, aku mengira Abu Bakrah berkata, dan harga diri kalian semua itu mulia sebagaimana kemuliaan hari kalian ini, di negeri kalian ini, pada bulan kalian ini. Kalian akan bertemu Tuhan kalian lalu Dia akan menanyakan amal perbuatan kalian. Jangan kalian kembali pada kesesatan setelah kematianku; kalian saling membunuh satu sama lain. Hendaknya, orang yang hadir menyampaikan ini kepada yang tidak hadir. Karena sebagian orang yang menyampaikan adakalanya lebih pintar daripada orang yang mendengar. (HR al-Bukhārī)

Rasulullah menginstruksikan agar umat mempelajari teknis pelaksanaan ibadah haji dari beliau ( $k h u d z \bar{u}$ 'annī manāsikakūm). Dalam hadis tersebut, beliau juga memerintahkan agar khutbahnya disampaikannya kepada saudara sesama Muslim yang tidak hadir (li yaballigh al-syāhid minkum al-ghā’ib). Hadis tersebut disampaikan Nabi pada saat Haji Wada'. Situasi ini merupakan indikator bahwa apa yang disampaikannya merupakan persoalan agama yang wajib diikuti oleh semua orang.

Dengan demikian, pesan-pesan Nabi saw. dalam Haji Wada' tersebut muncul dalam kapasitas beliau sebagai seorang utusan Tuhan yang bertugas menyampaikan risalah-Nya. Ritual haji, perlindungan terhadap jiwa, kemuliaan, kehormatan serta kewajiban menyampaikan ajaran tersebut kepada seluruh umat manusia merupakan pengejawantahan tugas beliau sebagai seorang rasul. 


\section{2. al-Qadä' (putusan hukum)}

Nabi saw. pernah mengalami suatu situasi di mana para sahabatnya yang menjadi warga negara yang dipimpinnya mengalami perseteruan. Pada saat itulah beliau bertindak sebagai penengah di antara orang-orang yang sedang berseteru. Dalam perseteruan tersebut, Nabi saw. menyatakan sesuatu untuk melerai pertikaian. Situasi yang menjadi pendorong munculnya sabda beliau tersebut dapat dianggap sebagai motif hadis. Sedangkan pernyataan untuk melerai itu sendiri, yang merupakan keputusan yang harus ditaati oleh mereka yang berseteru, menjadikan sabda beliau memiliki posisi khusus. Yaitu sebagai bentuk keputusan hukum (al-qada). Contohnya seperti hadis berikut,

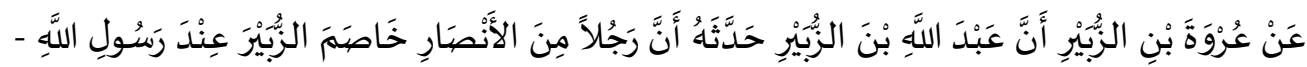

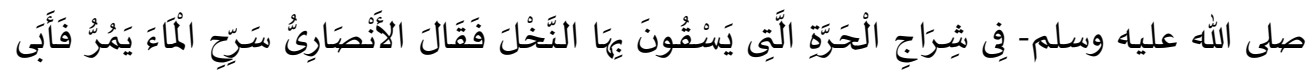

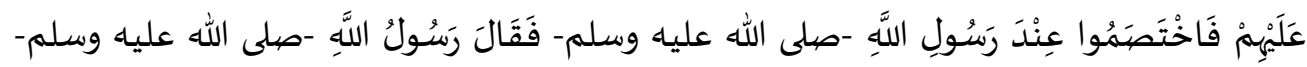

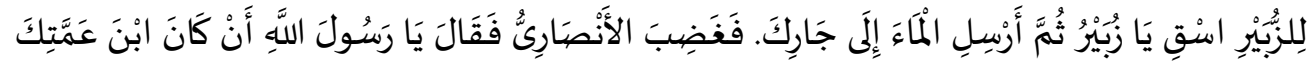



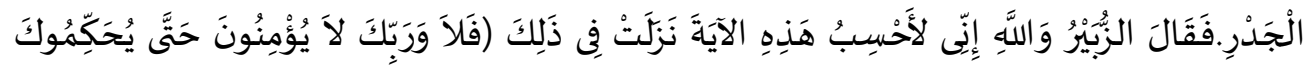

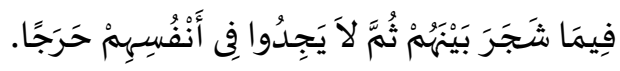
Dari 'Urwah bin al-Zubair, sesungguhnya Abdullah bin Zubair bercerita kepadanya, bahwa seorang laki-laki Ansar berselisih dengan al-Zubair di hadapan Rasulullah saw. atas mata air al-Harrah yang biasa mereka gunakan untuk mengairi pohon kurma. Laki-laki Anshar itu berkata, "Biarkan air mengalir!" Namun al-Zubair menolak. Akhirnya keduanya mengadukan hal itu kepada Rasulullah saw. Rasulullah saw. kemudian bersabda, "Alirilah kebunmu wahai Zubair, setelah itu berikanlah kepada tetanggamu." Tetapi laki-laki Ansar itu marah seraya berkata, "Wahai Rasulullah, apakah karena ia anak dari pamanmu!" Wajah Rasulullah saw. memerah, kemudian beliau bersabda, "Wahai Zubair, airilah kebunmu, setelah itu tahanlah hingga airnya kembali ke dalam tanah!" Abdullah bin al-Zubair berkata, "al-Zubair kemudian berkata, 'Sungguh, aku perkirakan bahwa ayat ini turun berkenaan dengan peristiwa itu, "Maka demi Tuhanmu, mereka (pada hakekatnya) tidak beriman hingga mereka menjadikan kamu hakim terhadap perkara yang mereka perselisihkan, kemudian mereka tidak merasa dalam hati mereka sesuatu keberatan terhadap putusan yang kamu berikan, dan mereka menerima dengan sepenuhnya'." (HR Muslim) 
Peran dan posisi Nabi saw. dalam narasi hadis tersebut jelas. Yaitu menengahi perseteruan antara Zubair dan seorang sahabat Anșār. Redaksi "mereka berseteru di hadapan Rasulullah" menunjukkan bahwa beliau diposisikan sebagai pemutus sengketa di antara mereka. Sedangkan pernyataan beliau "Wahai Zubair, airilah kebunmu, setelah itu tahanlah hingga airnya kembali ke dalam tanah!," merupakan keputusan hukum yang harusnya mengikat (dipatuhi oleh) mereka yang berseteru.

Situasi memberikan putusan hukum itu dikuatkan dengan kesaksian Zubair bahwa kajadian tersebut merupakan penyebab turunnya QS. al-Nisā': 65 tentang keharusan patuh pada putusan hukum Rasulullah saw. Hal ini menegaskan bahwa posisi Rasulullah saat itu adalah sebagai seorang hakim. Di sini, kita menemukan bahwa Alquran juga dapat menjadi indikator.

Ibn 'Āshūr menambahkan, hadis-hadis yang berbicara dalam konteks peradilan juga ditandai dengan redaksi اقض بيننا iqdi bainanā (berikan putusan kepada kami) dari seorang yang sedang berseteru atau pernyataan Rasulullah saw. semisal لاقضين بينكما láaqdiyanna bainakumā (saya akan memberi putusan kepada kalian). Keputusan-keputusan Rasulullah saw. telah dikompilasi oleh tokoh ulama mazhab Mālikī, al-Imam Muhammad bin Faraj Maulā ibn al-Ṭilā‘ al-Qurțubī dalam kitab Mumti '.58

Dapat dikatakan situasi perseteruan, kedatangan pihak-pihak yang berseteru kepada Nabi untuk menyelesaikan permasalahan mereka, kemudian pemosisian Nabi saw. sebagai hakim oleh pihak yang sedang berseteru merupakan situasi yang mendorong Nabi mengeluarkan kata-katanya. Sabdasabda itu lahir dalam konteks hukum. Indikator bahwa situasi saat itu adalah dalam konteks peradilan, adalah ditemukannya redaksi khasamalfa ikhatasamu (mereka berseteru), isqi ya zubair (alirkan airnya wahai zubair), dan dugaan Zubair bahwa kejadian tersebutlah yang memicu turunnya Alquran tentang kepatuhan kepada keputusan Nabi. Redaksi-redaksi tersebut merupakan indikator yang tercantum dalam narasi hadis (indikator internal).

Implikasinya jelas, yaitu tuntutan kepada pihak yang berseteru menghormati keputusan tersebut dengan cara taat. Sebagaimana pada umumnya putusan hukum, keputusan itu tidak berlaku bagi selain pihak yang berseteru.

\section{Haml al-Nafs 'Alā al-Akmal (meningkatkan kualitas mental)}

Adakalanya, Nabi bermaksud mengajarkan sikap-sikap mulia kepada para sahabatnya. Tujuan pengajaran ini seringkali luput dari amatan para ulama 
sehingga salah menempatkan suatu sabda Nabi untuk kepentingan lain semisal hukum. Ibn 'Āshūr menilai, sebagian ulama yang tidak menyadari tujuan tersebut seringkali terjebak dalam kesalah-pahaman dan menempatkan sunnah tidak sesuai konteksnya. ${ }^{59}$

Hal ini seperti dapat ditemukan dalam perintah khusus Nabi saw. kepada sahabat agar mereka menjalankan beberapa perilaku mulia seperti hidup sederhana dengan tidak memakai perhiasan seperti cincin emas. Perilaku ini bertujuan untuk menanamkan sikap hidup sederhana. Nabi saw. sangat menyadari bahwa kerusakan moral, agama, aturan dan kehidupan di dunia banyak disebabkan sikap berlebih-lebihan. Karenanya, beliau ingin mengajarkan kepada para sahabatnya agar bersikap sewajarnya. Contonya bisa dilihat dalam hadis berikut,

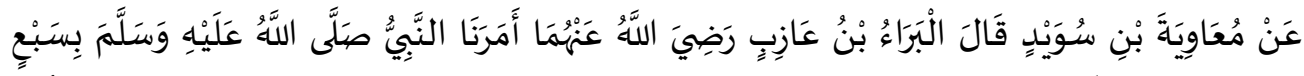

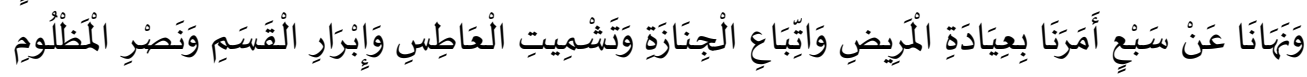

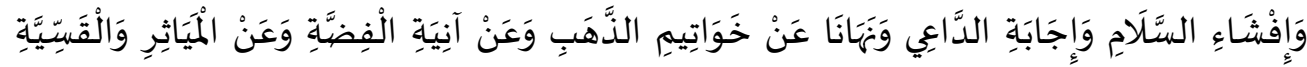



Dari Mu'awiyah bin Suwaid bahwa al-Bara' bin 'Azib radiyallähu 'anhuma berkata, "Nabi saw. telah memerintahkan kami tujuh perkara dan juga melarang kami dari tujuh perkara. Beliau memerintahkan kami untuk menjenguk orang sakit, mengantar jenazah, menjawab orang yang bersin, menunaikan sumpah, menolong orang yang terzalimi, menebarkan salam dan memenuhi undangan. Kemudian beliau melarang kami untuk mengenakan cincin emas, memakai bejana perak, mencabut uban, mengenakan al-Qassiyyah (pakaian yang bercampur dengan bahan sutera), al-Istibraq (kain yang dilapisi dengan bahan sutera) dan al-Dibaj (sejenis pakain dari kain sutera). (HR alBukhārī)

Al-Barra' bin 'Azib mengatakan bahwa Nabi saw. memerintahkan "kami". Kata "kami" dalam narasi hadis di atas berarti para sahabat. Dari sini, Ibn 'Āshūr memahami bahwa perintah itu hanya ditujukan untuk para sahabat. Bukan untuk seluruh umat sebagaimana dipahami selama ini menggunakan pendekatan yang tidak memilah-milah posisi Nabi saw. Untuk membuktikan bahwa perintah itu eksklusif, Ibn 'Āshūr mengutip hadis riwayat al-Nasāī berikut,



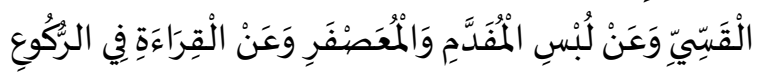


Dari 'Ali dia berkata, "Rasulullah saw. melarang saya -saya tidak mengatakan, beliau melarang kalian, memakai cincin emas, memakai pakaian berbordir sutra, memakai pakaian yang dicelup dengan warna menyala-nyala, yang dicelup dengan warna kuning, dan melarang membaca (Alquran) saat ruku'." (HR alNasā'ī)

Riwayat "Ali bin Abi Talib ini menggunakan redaksi "saya” dan "saya tidak mengatakan dia melarang kalian”. Menurut Ibn 'Āshūr, pernyataan 'Ali bin Abi Talib tersebut merupakan indikator penguat bahwa perintah dan larangan dalam hadis al-Barra' bin 'Azib tidak berlaku umum. Perintah dan larangan itu bersifat ekslusif. Lalu, apa yang diinginkan Nabi? Kenapa para sahabat memahami demikian? Al-Barra' dan 'Ali tentu lebih memahami maksud Nabi daripada kita yang hidup jauh di kemudian hari. Namun, berdasarkan kesaksian kedua sahabat tersebut dapat dipastikan bahwa pernyataan Nabi tersebut bersifat ekslusif. Dari sini, Ibn 'Āshūr memahami bahwa eksklusifitas itu didorong oleh keinginan Nabi saw. mengajarkan sifatsifat mulia. Hal ini terkait dengan tujuh perintah dan tujuh larangan, sebenarnya masing-masing memiliki ketentuan yang berbeda-beda tergantung situasi yang dihadapi seseorang. Ketujuh perintah tersebut (menjenguk si sakit, mengiring jenazah, mendoakan orang yang bersin, menolong orang terzalimi, membacakan salam, dan memenuhi undangan) sangat terkait dengan kebajikan sosial yang sangat situasional. Namun harus diakui bahwa ketujuhnya merupakan perilaku mulia. Sedangkan tujuh larangan (mengenakan cincin emas, memakai bejana perak, mencabut uban, mengenakan sutera jenis alQassiyyah, al-Istibraq dan al-Dibaj) seluruhnya lebih berkaitan dengan sikapsikap personal. Semua hampir tidak ada kaitannya dengan orang lain, kecuali bahwa dampak yang ditimbulkan kecintaan kepada benda-benda tersebut sangat berbahaya. Pertama bagi karakter pribadi mereka, selanjutnya pada sikap mereka secara sosial terhadap orang lain terutama terhadap mereka yang papa. Larangan-larangan personal ini menunjukkan bahwa ada suatu karakter mulia yang ingin dibangun oleh Nabi saw. pada diri sahabatnya. Inilah situasi yang dijelaskan dalam teks lain yang sekaligus menjelaskan motivasi etis Nabi saw. Situasi dan indikator dalam hadis ini disebutkan dalam narasi hadis dalam bentuk pernyataan sahabat. Dengan demikian, indikator ini tergolong indikator internal. Berbeda dengan sebelumnya dalam kasus indikator hukum yang situasinya dijelaskan oleh asbabul wurud, dalam konteks hadis tujuh larangan indikatornya terutama diambil dari kesaksian sahabat.

Implikasi eksklusifitas larangan ini ialah bahwa umat selain sahabat, tidak harus mengikutinya, sekalipun bila diikuti juga tidak terlalu bermasalah. Karena 
tujuan dari larangan tersebut adalah meningkatkan kualitas dan ketahanan mental seseorang.

Ulasan di atas menunjukkan bahwa pembacaan pemilahan (diferensiatif) ini terkadang akan menghasilkan pemahaman yang berbeda dengan apa yang selama ini diperoleh para ulama yang menggunakan pendekatan generalisir. Semisal dalam kasus penggunaan cincin emas bagi laki-laki, yang menurut Ibn 'Āshūr, larangan terhadapnya hanya ditujukan untuk para sahabat.

Pembacaan semacam ini pada akhirnya mengantarkan kita kepada motif dan motivasi Nabi (baca: murad al-nabi). Pembacaan ini juga akan mengantarkan kepada upaya melampaui pengertian literal suatu sabda Nabi (hadis Nabi). Hal ini karena motif berada di luar teks hadis, dan seringkali diabaikan dalam pembacaan hadis. Diagram berikut saya harap bisa menggambarkan posisi makna motif di hadapan makan literal,

Makna Teks dan Motif Sabda Nabi Saw.



Ibn 'Āshūr menemukan dua belas motif yang mendasari pernyataan Nabi. Bila dibuat diagram, maka lapisan dan irisan motif menjadi begitu banyak. Pengertian tekstual hanya menjadi satu di antara beberapa kemungkinan yang dapat diperoleh dari suatu hadis.

Peta Keragaman Motif Nabi saw.

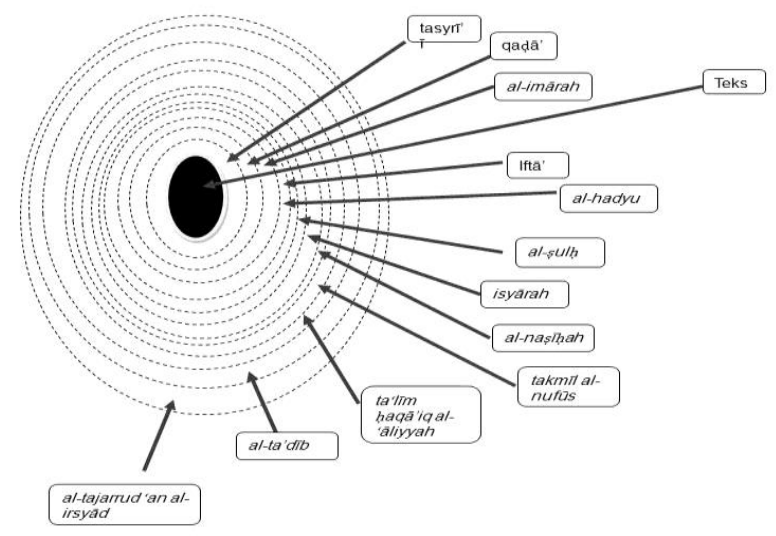


Lapisan-lapisan motif dalam diagram di atas bukan berarti dan tidak dapat diartikan sebagai suatu susunan hierarkhi. Dalam arti satu pengertian motif lebih didahulukan dalam pemaknaan hadis dibanding yang lain.Bahkan, Ibn 'Āshūr menegaskan bahwa suatu motif dapat dianggap ada bila dapat dibuktikan dengan suatu indikator yang mendukungnya. Baik indikator internal maupun eksternal. Dengan demikian, sistem indikator di sini menjadi penting dalam metode pemahaman hadis Ibn 'Āshūr.

Ditinjau dari pespektif analisis wacana, penekanan pada subjek dalam proses analisis wacana merupakan kecenderungan paradigma konstruktivisme. Kemunculan paradigma ini dipengaruhi oleh perkembangan filsafat fenomenologi yang menekankan pentingnya subjek, pengalamannya yang khas, dan pengandaian-pengandaian subjektif yang melingkupinya untuk menemukan pengertian yang dikehendaki subjek itu sendiri. Hal ini berbeda dengan kecenderungan paradigma positivis yang mengabaikan subjek dan lebih memfokuskan diri pada telaah kebahasaan dan memproduksi makna melalui sistem bahasa. Konstruktivisme menekankan pentingnya subjek. Asbab alwurud yang dirujuk dalam proses pemahaman ini hanyalah sebagai instrumen yang membantu penafsir sabda Nabi saw. agar dapat menemukan motif/makna orisinal-primordial yang dikehendaki beliau. Inilah bentuk pembacaan subjektif-konstruktivistik itu.

\section{Simpulan}

Ulasan di atas menuntun kepada sebuah kesimpulan mengenai modelmodel pemahaman hadis yang ada dalam tradisi Islam. Dari dua variabel yang diteliti; metode pemahaman hadis melalui ilmu matan hadis dan pemilahan peran yang didasarkan pada maqāṣid al-sharīah, dapat disimpulkan bahwa ada dua model paradigma pemahaman hadis yang telah berkembang. Yaitu paradigma positivistik dan konstruktivistik. Yang pertama lebih menekankan kepada aspek teks wacana dengan mengabaikan produsen wacana. Paradigma kedua, selain memperhatikan teks wacana, juga menaruh perhatian kepada pewacana. Yaitu dengan mencoba mengidentifikasi peran, motif dan motivasi si pewacana yang dalam hal ini adalah Nabi saw.

Terakahir, sebagai catatan, metode pemahaman hadis yang berkembang hingga saat ini belum mengadopsi paradigma kritis. Paradigma ini selain menaruh perhatian kepada teks-wacana, produsen-pewacana, juga memperhatikan struktur kuasa yang menciptakan individu pewacana. Wajar kiranya jika kemudian Nabi saw. ditempatkan di luar sejarah ketika seorang Muslim membaca hadis-hadis beliau. 


\section{Daftar Pustaka}

Al-Asymawī, Muhammad Sa'īd. Nalar Kritis Syari'ah, diterjemahkan oleh Luthfi Thomafi. Yogyakarta: LkiS. 2012.

Abu Zayd, Nasr Hamid, Mafhūm al-Nașs Dirāsah Fī 'Ulūm al-Qur'ān.

Audah, Jasser. Maqūsid al-Sharī'ah Dalīl li al-Mubtadi' diterjemahkan ke dalam bahasa Arab oleh 'Abd al-Lațif al-Khayyāt. Herndon: The International Institute of Islamic Thought. 2011.

Bakkār, Muhammad Mahmud Ahmad. Bulügh al-Āmāl min Muștalặ al-Hadīṣ wa al-Rijäl. Kairo: Dar al-Salam. 2012.

Al-Bukhari, Muhammad bin Ismācill. Șahih al-Bukhāri.

Al-Dimasyqi, Ibrahim bin Muhammad bin Kamal al-Din al-Syahir bi Ibn Hamzah. al-Bayān wa al-Ta'rīf $f \bar{i}$ Asbāb wurūd al-Hadīs al-Syarîf. Halb Shahba': Mathba'ah al-Baha'. 1329.

Eriyanto, Analisis Wacana Pengantar Analisis Teks Media. Yogyakarta: LkiS. 2011.

Al-Harawī, Abū 'Ubaid al-Qāsim bin Sallam. Gharīb al-Hadìis. Beirut: Dar al'Ilmiyah. 2003.

Hasani, Isma'il. Nazariyat al-Maqūșid 'Inda al-Imām al-Ṭähir ibn 'Āshūr. Herndon: The Internationale Institute of Islamic Thought. 1995.

Huda M. Khoirul. Membaca Ikhtiläf al-Hadìs Karya al-Syäfi., makalah kelas. Tidak dipublikasikan.

Membaca Ikhtiläf al-Hadīs Karya al-Syäfi'i, Sejarah

Kelahiran, Ragam Pertentangan dan Metode Penyelesaian. Makalah kelas, tidak diterbitkan.

Ibn 'Āshūr, Muhạmmad al-Ṭāhir, Maqāṣid al-Sharī'ah al-Islāmiyyah. Tunis: Dar al-Suhnun. 2006.

Muhammad al-Ṭāhir. Ușūl al-Nizām al-Ijtimā'‘̄ fì al-Islām. Tunis: al-Syirkah al-Tūnisiyyah Li al-Tauzī‘. Tt.

Ibn Qutaybah, Abū Muhammad Abdullah bin Muslim. Ta'wīl Mukhtalif alHadìth wa al-Radd 'ala Man Yurìb fì al-Akhbār al-Mudda'à 'Alayha alTanäqud. Kairo: Dar Ibn 'Affan. 2009.

Al-Jauziyyah, Ibn Qayyim. I'lam al-Muwaqqi ìn 'An Rabb al-'Alamin. Dammam: Dar Ibn al-Jauzi. 1463.

Al-Jawzī Abū al-Faraj 'Abd al-Raḥmān bin 'Ali bin. Gharīb al-Hadịth. Beirut: Dar al-Kutub al-'Ilmiyyah. 2004.

Al-Khādimī, Nur al-Dīn bin Mukhtār. al-Maqāṣid al-Syar'iyyah, Ta'rîfuhā, Ams்ilatuhā, Hujjiyyatuhā. Riyadh: Kunūz Isybiliyā. 2003. 
Al-Maisāwī, Muhammad al-Ṭahir. al-Syaikh Muhammad al-Ṭāhir ibn 'Āshūr wa al-Masyrū' alladzi lam Yaktamil, dalam Maqāṣid al-Sharī'ah al-Islämiyyah. Abdal: Dar al-Nafa'is. 2001.

Al-Sahibani, Ali bin 'Umar bin Muhammad, al-Ta'wīl fi Gharīb al-Hadìs min Khilāl Kitāb al-Nihāyah li Ibn al-Aj̇̄̄r. Riyadh: Maktabah al-Rusy. 2009.

Al-Shāfi'ī, Muhammad bin Idris. Ikhtilaf al-Hadìth. Mansurah: Dar al-Wafa' li al-Tibā'ah. 2001.

Al-Suyūṭī, Jalāl al-Dīn 'Abd. al-Raḥmān. al-Itqān fì 'Ulūm al-Qur'ān. Beirut: Dar al-Kutub al-'Ilmiyyah. 2010.

Al-Syāṭibī, Abu Ishāq. al-Muwāfaqāt fì Ușūl al-Sharīah. Beirut: Dar al-Kutub al-'Ilmiyah. Tt.

Tharabisi, George. Min Islām al-Qur'ān Ilā Islām al-Hadìth. Beirut: Dār al-Sāqī. 2010.

Al-Zaydi, Kasid Yasir dan Walid bin Ahmad al-Husain. Manhaj Abī 'Ubaid fi Tafsìr Gharīb al-Hadìis. Leedds: Majallah al-Hikmah. 1999.

\section{Catatan Akhir:}

${ }^{1}$ Nasr Hamid Abu Zayd, Mafhūm al-Naṣs Dirāsah Fī 'Ulūm al-Qur’ān, (Beirut: 11 ,

${ }^{2}$ George Tharabisi, Min Islàm al-Qur'àn Ilà Islām al-Hadìth, (Beirut: Dār al-Sāqī, 2010), cet ke-1, hlm. 619-625

${ }^{3}$ Ibn Qayyim al-Jauziyyah, I'làm al-Muwaqqi'in 'An Rabb al-'Alamin, (Dammam: Dar Ibn al-Jauzi, 1463), jilid 2, 354

${ }^{4}$ Abū al-Faraj 'Abd al-Raḥmān bin 'Ali bin al-Jawzī, Gharīb al-Hadìth, (Beirut: Dar al-Kutub al-'Ilmiyyah, 2004), cet. Ke-1, 1.

${ }^{5}$ Lihat Muhammad bin Idris al-Shāfi'ì, Ikhtilaf al-Hadìth, (Mansurah: Dar alWafa' li al-Tibā'ah, 2001), cet. ke-1, dan Abū Muhammad Abdullah bin Muslim bin Qutaybah, Ta'wīl Mukhtalif al-Hadìth wa al-Radd 'ala Man Yurīb fì al-Akhbār alMudda'à 'Alayha al-Tanāqud, (Kairo: Dar Ibn 'Affan, 2009), cet. ke-2.

${ }^{6}$ Eriyanto, Analisis Wacana Pengantar Analisis Teks Media (Yogyakarta: LKiS, 2011), cet. Ke-1, h. 3-7

${ }^{7}$ M. Khoirul Huda, Membaca Ikhtilāf al-Hadīi Karya al-Syāfi ‘i, Sejarah Kelahiran, Ragam Pertentangan dan Metode Penyelesaian. Makalah kelas, tidak diterbitkan.

${ }^{8}$ M. Khoirul Huda, Membaca Ikhtiläf al-Hadìis Karya al-Syāfi 'i, makalah kelas. Tidak dipublikasikan. 
${ }^{9}$ Hadis diriwayatkan oleh al-Shāfi'ī dalam kitabnya, Ikhtiläf al-Hadìis, (Beirut: Dar al-Kutub al-'Ilmiyyah, 2008), cet. Ke-1, h. 478

${ }^{10}$ al-Shāfi'ī dalam kitabnya, Ikhtilāf al-Hadīis, (Beirut: Dar al-Kutub al-'Ilmiyyah, 2008), cet. Ke-1, h. 478

${ }^{11}$ al-Shāfi‘ī dalam kitabnya, Ikhtilāf al-Hadīs, h. 478

${ }^{12}$ Lihat Abū 'Ābdillah Muhammad bin Idrīs al-Shāfi'ī, Ikhtilāf al-Hadīì, h. 488

${ }^{13}$ al-Shāfi'ī dalam kitabnya, Ikhtilāf al-Hadìs, h. 478

${ }^{14}$ al-Shāfi'ì dalam kitabnya, Ikhtilāf al-Hadìis, h. 478

${ }^{15}$ Lihat Abū 'Ābdillah Muhammad bin Idrīs al-Shāfi'ī, Ikhtilāf al-Hadīs..., h. 523

${ }^{16}$ Lihat Abū 'Ābdillah Muhammad bin Idrīs al-Shāfi'ī, Ikhtilāf al-Hadīis..., h. 523

${ }^{17}$ Kasid Yasir al-Zaydi dan Walid bin Ahmad al-Husain, Manhaj Abi 'Ubaid $f i$ Tafsīr Gharīb al-Hadīs, (Leedds: Majallah al-Hikmah, 1999), cet. Ke-1, h. 30-32, dan Ali bin 'Umar bin Muhammad al-Sahibani, al-Ta'wīl fi Gharīb al-Hadìs min Khiläl Kitāb al-Nihāyah li Ibn al-Asìir, (Riyadh: Maktabah al-Rusy, 2009), cet. Ke-1, h. 129134

${ }^{18}$ Abū 'Ubaid al-Qāsim bin Sallam al-Harawī, Gharīb al-Hadīis, (Beirut: Dar al'Ilmiyah, 2003), cet. Ke-2, juz 2, h. 336

${ }^{19}$ Abū 'Ubaid al-Qāsim bin Sallam al-Harawī, Gharīb al-Hadìs, (Beirut: Dar al'Ilmiyah, 2003), cet. Ke-2, juz 2, h. 336

${ }^{20}$ Muslim bin Hajjaj, Șaḩị̆ Muslim, juz 1, hlm. 51

${ }^{21}$ Muhammad bin Ahmad al-Khatthabi, Gharīb al-Hadìs, juz 2 hlm. 49

${ }^{22}$ Muhammad Mahmud Ahmad Bakkār, Bulūgh al-Āmāl min Muṣtalah al-Hadīṣ wa al-Rijäl, (Kairo: Dar al-Salam, 2012), cet. Ke-1, h. 381

${ }^{23}$ Muhammad bin Ismāî̀l al-Bukhari, Șahih al-Bukhāri, juz 6, h. 2551

24 Para ahli fikih yang melepaskan hadis tersebut dari konteksnya telah menafsirkan niat ke dalam berbagai aspek kehidupan Muslim. Kepentingannya pun sudah berbeda dari makna yang dikehendaki Nabi saw. pada mulanya. Hal ini wajar mengingat ahli fikih hanya membutuhkan teks sebagai dasar hukum tanpa mempedulikan lagi dalam konteks apa hadis itu muncul.

${ }^{25}$ Jalāl al-Dīn 'Abd. al-Raḥmān al-Suyūṭī, al-Itqān fì 'Ulūm al-Qur'ān, (Beirut: Dar al-Kutub al-'Ilmiyyah, 2010) cet. ke-2, juz 1, h. 52

${ }^{26}$ Ibrahim bin Muhammad bin Kamal al-Din al-Syahir bi Ibn Hamzah alDimasyqi, al-Bayān wa al-Ta'rīf fì Asbāb wurūd al-Hadīs al-Syarîf, (Halb Shahba': Mathba'ah al-Baha', 1329), h. 5

${ }^{27}$ Kemampuan ini membantu Ibn 'Āshūr mengakses pemikiran Eropa dengan mudah. Banyak di antara pemikirannya di kemudian hari dipengaruhi oleh tradisi pemikiran EropaPrancis seperti ide tentang rasionalisme (al-'aqläniyyah), kebebasan (al-hurriyyah), toleransi (alsamāhah) dan kesetaraan (al-musāwāh). Keempat ide tersebut bahkan dianggap Ibn 'Āshūr sebagai bagian dari prinsip syariat (maqūsid al-sharī'ah). Ibn 'Āshūr juga menerima demokrasi dan kesetaraan gender. Lihat Muhammad al-Ṭāhir ibn 'Āshūr, Usūul al-Nizām al-Ijtimā' $\bar{\imath}$ fì al- 
Isläm, (Tunis: al-Syirkah al-Tūnisiyyah Li al-Tauzī‘, tt), cet. Ke-2, h. 25, 97, 143, 159, 213, 226, bandingkan dengan karyanya yang lain, Maqūṣid al-Sharì'ah al-Islämiyyah. (Tunis: Dar alSahnūn Li al-Nasyr wa al-Tauzī‘, 2006), h. 58, 93, 126

${ }^{28}$ Isma'il al-Hasani, Nazariyat al-Maqūsid 'Inda al-Imām al-Ṭāhir ibn 'Āshūr..., h.81

${ }^{29}$ Lihat pengantar Abdullah Daraz dalam Abu Ishāq al-Syātịīi, al-Muwāfaqāt fì Ușūl alSharì'ah (Beirut: Dar al-Kutub al-'Ilmiyah, tt), h. 10

${ }^{30} I$ Isma'il al-Hasani, Nazariyat al-Maqāsid 'Inda al-Imām al-Ṭāhir ibn 'Āshūr..., h. 78

${ }^{31}$ lihat pengantar Muhammad al-Ṭāhir al-Maisāwī, al-Syaikh Muhammad al-Ṭāhir ibn 'Āshūr wa al-Masyrū' alladzi lam Yaktamil, dalam Maqūsid al-Sharī'ah al-Islämiyyah (Abdal: Dar al-Nafa' is, 2001), cet. Ke-2, h. 86

${ }^{32}$ Tidak lama setelah itu, 'Allāl al-Fasī menulis kitabnya Maqāsid al-Sharī‘ah al-Islāmiyyah wa Makārimuhā (ttt: Dar al-Gharb al-Islāmi, 1993), cet. Ke-3. Dan menjadikan maqāṣid sebagai mata kuliah resmi di Universitas Muhammad V Rabat, Maroko. Hingga kini, kajian maqāṣid banyak dipelopori oleh ilmuwan-ilmuan asal Arab-Barat ini.

${ }^{33}$ Isma'il al-Hasani, Nazariyat al-Maqāsid 'Inda al-Imām al-Ṭāhir ibn 'Āshūr, (Herndon:

The Internationale Institute of Islamic Thought, 1995), h.22

${ }^{34}$ Muhạmmad al-Ṭāhir ibn 'Āshūr, Maqūsid al-Sharī'ah.., h. 6

${ }^{35}$ Muhammad al-Ṭāhir ibn 'Āshūr, Maqūșid al-Sharī 'ah.., h.13

${ }^{36}$ Muhammad al-Ṭāhir ibn 'Āshūr, Maqūṣid al-Sharī'ah.., h. 49

${ }^{37}$ Lihat Nur al-Dīn bin Mukhtār al-Khādimī, al-Maqāṣid al-Syar'iyyah, Ta'rīfuhā, Amsilatuhā, Hujjiyyatuhā (Riyadh: Kunūz Isybiliyā, 2003), cet. Ke-1, h. 24

${ }^{38}$ Muhammad al-Ṭāhir ibn 'Āshūr, Maqūsid al-Sharī'ah.., h.23

${ }^{39} \mathrm{Ibn}$ 'Āshūr menunjuk model pemahaman kaum Z̄āhiriyyah dan sebagian Ahli Hadis yang terpaku pada pengerian tekstual.

40 Dulu para ulama mempunyai tradisi mengunjungi Haramain, selain untuk mendapatkan ilmu juga untuk melihat langsung peninggalan Nabi saw., sahabat dan para pengikutnya. Bagaimana suatu ajaran dipraktikkan oleh komunitas yang mempunyai komitmen kesetiaan yang begitu tinggi. Al-Bukhārī merupakan ahli hadis yang menyadari pentingnya berkunjung ke Tanah Haram untuk mempelajari hal-hal tersebut. Bahkan dalam kitabnya, alJāmi al-Ṣah̄ḥ beliau membuat satu bab khusus yang menceritakan diskusi antara 'Āṣim dan Anas bin Mālik. Anas menekankan bahwa dirinya lebih tahu daripada 'Āṣim karena dia adalah orang asli Madinah dan kejadian yang dilansir hadis yang dibawa 'Āṣim terjadi di kampungnya. 'Āṣim menyadari hal itu dan menerima informasi dari Anas. Al-Bukhārī berbeda dari ahli-ahli hadis yang lain karena kepekaannya ini.

${ }^{41}$ Muhammad al-Ṭāhir ibn 'Āshūr, Maqūṣid al-Sharī'ah.., h. 25

${ }^{42}$ Muhammad al-Ṭ̄āir ibn 'Āshūr, Maqāsid al-Sharī'ah..., h. 25

${ }^{43}$ Muhammad al-Ṭāhir ibn 'Āshūr, Maqūṣid al-Sharī'ah.., h. 25

${ }^{44}$ Muhamammad al-Ṭāhir ibn 'Āshūr, Maqūsid al-Sharī'ah..., h. 25

${ }^{45}$ Muhammad al-Ṭāhir ibn 'Āshūr, Maqūsid al-Sharī'ah..., h. 26

${ }^{46}$ Muhammad al-Ṭāhir ibn 'Āshūr, Maqūsid al-Sharī'ah..., h. 26

${ }^{47}$ Muhammad al-Ṭāhir ibn 'Āshūr, Maqụ̄sid al-Sharī'ah..., h. 27

${ }^{48}$ Redaksi hadisnya, 


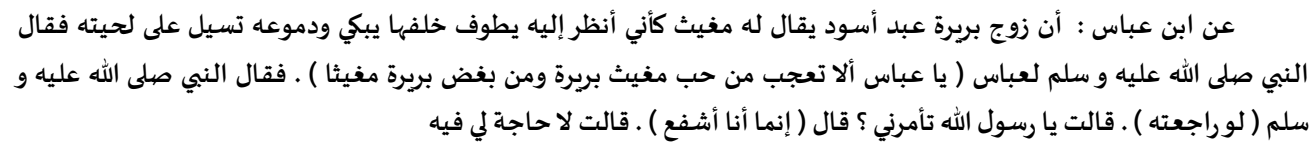

Dari Ibn 'Abbās bahwa suami Barīrah adalah budak berkulit hitam. Dia disebut-sebut bernama Mughith. Sepertinya, aku melihat dia berjalan di belakang Barīrah dalam keadaan menangis. Air matanya meleleh di atas janggutnya. Nabi saw. berkata kepada 'Abbās, "Abbās! Apa kamu tidak kagum dengan cinta Mughith, dan kebencian Barīrah pada Mughith?" Nabi bersabda, "Andai saja kamu mau kembali kepadanya (Mughith)." Barīrah berkata, "Apakah Anda memerintahkan saya, wahai Rasulullah?" Nabi saw. berkata, "Saya hanya ingin menolong (Mughith)." Barīrah berkata, "Aku sudah tidak butuh dia."

(HR al-Bukhārī)

Dalam hadis ini, Barīrah bertanya tentang apakah pernyataan Nabi saw. itu dalam konteks perintah agama yang wajib ditaati atau bukan. Di sini Barīrah memastikan pernyataan tersebut dengan bertanya tentang motif perintah. Setelah Nabi saw. menjawab bahwa perintah itu bukan dalam kapasitas sebagai penyampai wahyu, Barīrah dengan tegas mengatakan dia tidak bisa kembali pada mantan suaminya. Para sahabat bisa bertanya langsung kepada Nabi apakah perintahnya dalam rangka tasyri'/tabligh atau bukan. Problem orang-orang yang tidak bertemu dengan beliau ialah bagaimana mengidentifikasi motif-motif itu.

${ }^{49}$ Redaksi hadisnya,

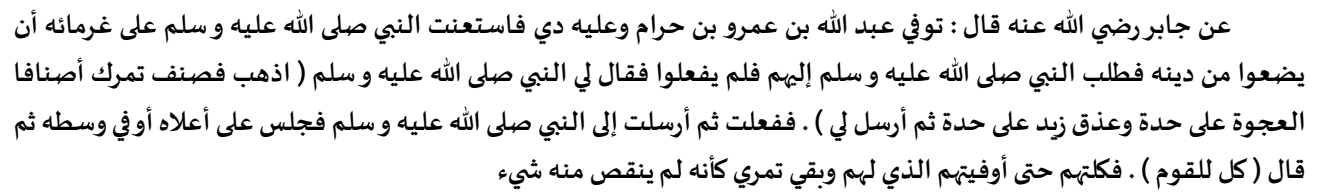

“Dari Jābir raḍiyallahu 'anhu, dia berkatan, “Abdullah bin 'Amr bin Harām (ayahnya) meninggal. Dia mempunyai tanggungan utang. Aku (Jābir) meminta pertolongan kepada Nabi saw. agar mau membujuk para pemilik hutang untuk membebaskan hutangnya. Nabi saw. sudah meminta mereka melakukan itu, tapi mereka tidak menjalankannya. Nabi saw. berkata kepadaku, "Pergilah, susun kurmamu. Ajwah dalam satu kelompok, 'Adzqu Zaid dalam satu kelompok, lalu kirimkan kepadaku." Aku melakukan perintah Nabi saw. lalu mengirimkannya pada beliau. Beliau menduduki bagian atas kurma, atau tengahnya. Kemudian beliau berkata, "Takar untuk para penghutang itu." Aku menakar untuk mereka, hingga aku membayar lunas utang mereka. Dan kurma milikku masih utuh seakan tidak berkurang sedikit pun.

(HR al-Bukhārī)

${ }^{50}$ Muḥammad al-Ṭāhir ibn 'Āshūr, Maqūsid al-Sharī'ah al-Islāmiyyah, (Tunis: Dar alSuhnun, 2006), h. 26

51 Istilah ini digunakan Jasser Audah ketika mengupas tentang sumbangan al-Qarrāfī dalam pemikiran maqāṣid. Dia dipandang tokoh yang memelopori proses diferensiasi posisi Nabi saw., terutama untuk mengungkap motif Nabi di satu sisi dan mengetahui maqāṣīd alSharī'ah dalam suatu hadis di sisi lain. Lihat Jasser Audah, Maqāsid al-Sharī'ah Dalīl li alMubtadi' diterjemahkan ke dalam bahasa Arab oleh 'Abd al-Laṭif al-Khayyāṭ (Herndon: The International Institute of Islamic Thought, 2011) cet. Ke-1, h. 47

52 Terma ini digunakan Jasser Audah ketika membahas mengenai bentuk-bentuk pengembangan maqāṣid di era kontemporer yang di antaranya ialah yang menjadikan 
hadis/sunnah sebagai objeknya. Jasser Audah memperkenalkan istilah fahm maqāsid alnabawiyyah (pemahaman motif-motif Nabi saw), dan meminjam konsep diferensiasi al-Qarrāfi berikut pengembangan lebih lanjut oleh Ibn 'Āshūr. Lihat dalam Jasser Audah, Maquạsid alSharī 'ah Dalīl li al-Mubtadi', h. 86

${ }^{53}$ Belum diketahui secara jelas apakah sifät dan ạ̣wāl dimaksudkan pada satu konsep yang sama atau bukan. Jasser Audah hanya menyebut ạ̣wäl sebagai motif. Hal ini mengindikasikan bahwa ậwāl identik dengan sifät. Jasser Audah juga menegaskan ạ̣wāl tersebut tidak lain merupakan maqūṣid (rasul). Jasser Audah, Maqūṣid al-Sharī 'ah Dalìl li al-Mubtadi', h. 86

${ }^{54}$ Muhammad al-Ṭāhir ibn 'Āshūr, Maqūsid al-Sharī'ah ..., h. 25

${ }^{55}$ Muhammad al-Ṭāhir ibn 'Āshūr, Maqūṣid al-Sharī'ah ..., h. 27

${ }^{56}$ Muḥammad al-Ṭāhir ibn 'Āshūr, Maqūṣid al-Sharì‘ ah ..., h. 36

${ }^{57}$ Ibn 'Āshūr tidak mengungkapkan secara tegas apa yang dimaksud syarī'ah atau tasyrī' dalam pemikirannya. Muhammad Sa'īd al-Asymawi telah meneliti asal-usul kata syariah termasuk penggunaannya dalam tradisi Yahudi, Kristen, bahkan tradisi kuno Mesir dan Yunani. Awalnya kata tersebut merujuk pada ritus penyajian korban, melangsungkan nazar, melindungi banyak orang dari penyakit kemudian bergeser penggunaannya untuk segala sesuatu yang termaktub dalam kitab Musa (kitab Kejadian, Keluaran, Imamat, Bilangan, dan Ulangan) yang berisikan perintah, kewajiban, hukum, dan nasihat (yang meliputi legislasi hukum-hukum dan muamalah). Kata tersebut mengalami pergeseran makna kembali menjadi segala hukum agama Yahudi, dan khususnya tafsir-tafsir, hukum-hukum, dan keterangan-keterangan yang ada dalam kitab Talmud. Pergeseran makna juga terjadi dalam tradisi Islam. Al-Asymawi memilah antara penggunaan kata tersebut dalam Alquran dan tradisi fiqh Islam. Alquran menggunakan kata syariat dengan arti țarīqah. Kemudian ia mengalami pergeseran menjadi setiap hukum agama. Segala sesuatu yang terdapat dalam Alquran seperti jalan-jalan agama, aturan ibadah, legislasi hukum dan muamalah merupakan syariat. Sedangkan dalam fiqh Islam, makna kata syariat ialah segala hukum agama, aturan ibadah legislasi hukum, muamalah; segala yang terdapat dalam hadis Nabi, segala ajaran tokoh agama. Oleh karena itu, sumber-sumber hukum syariat yang tentu saja melampaui pengertian kebahasaan kata syariat itu sendiri, seperti Alquran, hadis, ijma dan qiyas merupakan syariat juga. Pelacakan al-Asymawi menghantarkan pada kesimpulan bahwa makna syariat dalam tradisi Islam sangat luas meliputi sumber agama seperti Alquran, hadis, ijma, qiyas, tafsir-tafsir, serta pendapat hukum seorang tokoh agama. Seluruh yang berhubungan dengan agama dan apa yang khusus berkaitan dengan legislasi hukum, baik yang terdapat dalam Alquran, hadis, ijma dan qiyas. Seluruhnya merupakan syariat. Lihat Muḥammad Sa'īd al-Asymawī, Nalar Kritis Syari'ah, diterjemahkan oleh Luthfi Thomafi (Yogyakarta: LKiS, 2012), cet. Ke-1, h.23-26. Penulis menemukan pengertian yang berbeda dengan apa yang dikehendaki al-Asymawi yang cenderung meluas untuk konteks kata tasyrī ${ }^{\circ}$ dalam pemikiran Ibn 'Āshūr. Syariat menurutnya ialah segala yang datang dari Tuhan (baca: wahyu). Dengan demikian, aktifitas penyampaian wahyu itu disebut sebagai tasyri‘. Syariat bisa disamakan dengan risālah, sedangkan aktifitas menyampaikan risālah (tablīgh al-risālah) disebut tasyrī"

${ }^{58}$ Muhammad al-Ṭāhir ibn 'Āshūr, Maqūsid al-Sharī'ah..., h. 28

${ }^{59}$ Muhammad al-Ṭāhir ibn 'Āshūr, Maqūsid al-Sharī'ah..., h. 32 